\title{
Ediacaran-Paleozoic subsidence history of the Volyn-Podillya-Moldavia Basin (W and SW Ukraine, Moldova, NE Romania)
}

\author{
Paweł POPRAWA ${ }^{1,{ }^{*},}$, Natalia RADKOVETS ${ }^{2}$ and Johannes RAUBALL ${ }^{3}$ \\ 1 AGH University of Science and Technology, Al. A. Mickiewicza 30, 30-053 Kraków, Poland \\ 2 Institute of Geology and Geochemistry of Combustible Minerals of the NAS of Ukraine, Naukova 3a, 79060 Lviv, Ukraine \\ 3 Chair Petroleum Geology, Montanuniversität Leoben, 8700 Leoben, Austria
}

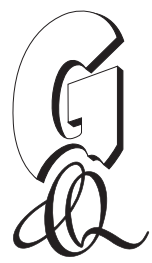

Poprawa, P., Radkovets, N., Rauball, J., 2018. Ediacaran-Paleozoic subsidence history of the Volyn-Podillya-Moldavia Basin (W and SW Ukraine, Moldova, NE Romania). Geological Quarterly, 62 (3): 459-486, doi: 10.7306/gq.1418

\begin{abstract}
Tectonic subsidence history was analysed for the Ediacaran-Paleozoic Volyn-Podillya-Moldavia Basin, by performing 1D backstripping for 21 boreholes located in western and SW Ukraine, Moldova and NE Romania. Tectonic subsidence history is coherent across the area studied. Development of the basin commenced with an Ediacaran phase of extension, initiated with the emplacement of rift-related volcanic rocks and associated with rapid syn-rift tectonic subsidence. During this event, tectonic subsidence increased towards the SW, i.e. towards the edge of the East European Craton, where the Ediacaran rift zone was located. At that time, a rift developed along the whole SW margin of the East European Craton from Scandinavia to the Black Sea. Development of this large extensional basin was related to the latest stages of break-up of the Precambrian supercontinent Rodinia/Pannotia and ultimately the formation of the Tornquist Ocean. The latest Ediacaran to Late Ordovician tectonic subsidence pattern was characteristic of the post-rift thermal sag stage of extensional basins. The SW margin of the newly formed Baltica, including the area studied, became a passive continental margin. The late Cambrian uplift and erosion was presumably related to a far-field effect of contractional events or intra-plate stresses. Since the Late Ordovician, a gradual change to a collisional tectonic setting is observed across the SW margin of Baltica. In the study area, this is indicated by a systematic increase in subsidence rate from Wenlock to Early Devonian time, creating subsidence curves with convex shapes typical of foreland basin development. The Silurian to Early Devonian Volyn-Podillya-Moldavia Basin is interpreted here as a flexural foredeep related to a Caledonian collision zone located further to the SW. The prominent diachroneity in the initiation of the foredeep basin development at a scale of the whole SW margin of Baltica is coherent with a model of oblique collision of Avalonia and Baltica. During the Pragian-Emsian, the basin was part of a system of post-collisional Old Red basins, with subsidence driven presumably by lithospheric isostatic imbalance resulting from the Caledonian collision and development of an accretionary wedge. Middle to Late Devonian short-term phases of rapid subsidence in small depocentres might be regarded as an indication of a transtensional tectonic regime.
\end{abstract}

Key words: Ediacaran-early Paleozoic, Volyn-Podillya-Moldavia Basin, tectonic subsidence, backstripping.

INTRODUCTION

The Volyn-Podillya-Moldavia Basin (VPMB), the subject of the current study (see Fig. 1 for location), is part of an extensive system of Neoproterozoic-Paleozoic sedimentary basins which developed along the western slope of the East European Craton (EEC), collectively referred to as the Peri-Tornquist Basin System. The VPMB is located at the southwestern slope of the EEC and during the early Paleozoic coincided with the SW (in present coordinates) slope of Baltica. The western limit of the basin is associated with the Teisseyre-Tornquist Zone (Fig. 1), which acts as a boundary between the EEC and the Trans-European Suture Zone. The eastern limit of the VPMB is of erosional nature and is delineated by the western edge of the Ukrainian Shield.

* Corresponding author, e-mail: ppop.ecr@gmail.com Received: November 27, 2017; accepted: April 9, 2018; first published online: June 6, 2018
Sedimentation in the VPMB continued from the Neoproterozoic to the Carboniferous (Fig. 2); however, this section of the basin includes numerous hiatuses. Due to post-Variscan erosion, the Middle and Upper Devonian and Carboniferous strata are currently limited to the zones located in the western and southern part of the area studied (Figs. 3 and 4). More laterally extensive and better preserved is the Ediacaran-lower Paleozoic-Lower Devonian section (Fig. 4), which is a major subject of interest for the current study.

Understanding of tectonic processes governing the origin and evolution of the VPMB is still incomplete. In this paper, 1D backstripping is applied to analyse tectonic subsidence of the VPMB during the Ediacaran-Paleozoic with the assumption that some of tectonic subsidence mechanisms reveal characteristic and distinguishable patterns of subsidence curves. This applies particularly to rift basins, passive margins, foredeeps, strike-slip basins and intra-cratonic basins (e.g., McKenzie, 1978; Falvey and Middleton, 1981; Angevine et al., 1990; Allen and Allen, 1990; King, 1994; Busby and Ingersoll, 1995).

Tectonic subsidence analysis is routinely applied for investigation of tectonic controls on sedimentary basin formation (e.g., 


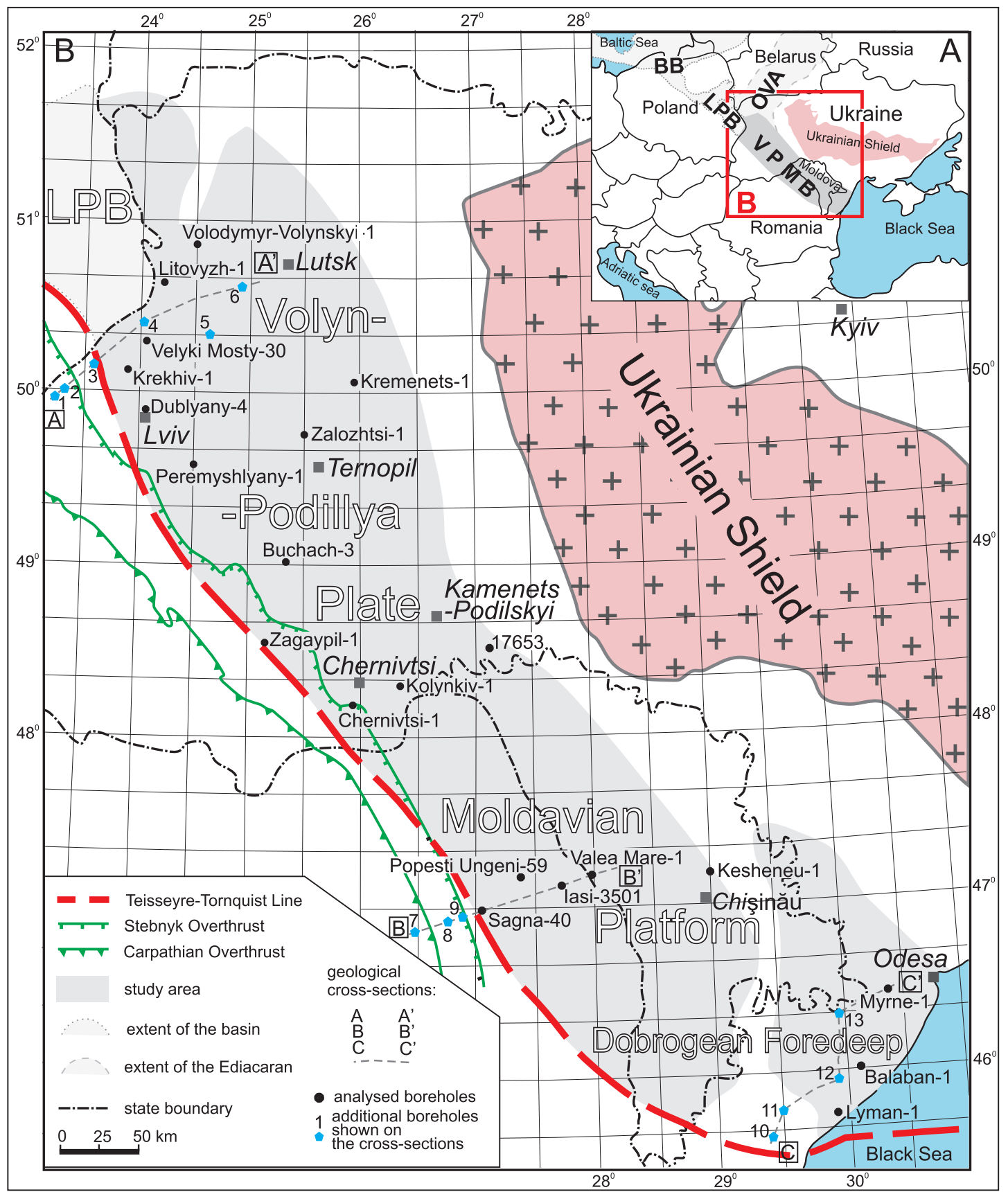

Fig. 1A - location of the study area (B) on the background of central and eastern Europe; VPMB - Volyn-Podillya-Moldavia Basin, LPB - Lublin-Podlasie Basin, BB - Baltic Basin, OVA - Orsha-Volyn Aulacogen; B map of the study area with locations of the boreholes analysed; additional boreholes shown on cross-sections (Fig. 3): 1 - Pidluby 124, 2 - Pidluby 103, 3 - Rava Ruska 1, 4 - Zhuzhelyany 1, 5 - Sushne 1, 6 - Gorokhiv 1, 7 Bodesti 5001, 8 - Roman 13, 9-Roman 14, 10 - Furmanivka 1, 11 - Stari Troyany 1, 12 - Zhovtyi Yar 1, 13 - Vugilna 7

Steckler and Watts, 1978). This technique was commonly used to analyse lower Paleozoic basins (e.g., Bond et al., 1984; Levy and Christie-Blick, 1991; King, 1994; Kominz, 1995; Waldron et al., 1996; Poprawa et al., 1999; Poprawa and Pacześna, 2002; Poprawa, 2006a, b). However, such an approach has not yet been applied to the VPMB previously. Twenty-one representative boreholes from western and southwestern Ukraine, Moldova and NE Romania were studied (see Fig. 1 for location). Backstripping results are discussed and used to reconstruct a tectonic history controlling the onset and rate of subsidence within the VPMB.

\section{GEOLOGICAL SETTING}

The VPMB is located in the southwestern part of the EEC and is traditionally divided into the following individual tectonic units: Volyn-Podillya Plate, Moldavian Platform and Dobrogean Foredeep (Figs. 1 and 4). The present structure of the SW slope of the EEC is partly a result of post-depositional uplift, erosion and deformation (e.g., Środoń et al., 2013), though in part is also a consequence of lateral differences of syn-depositional development. As a result, we refer to the northern and the 


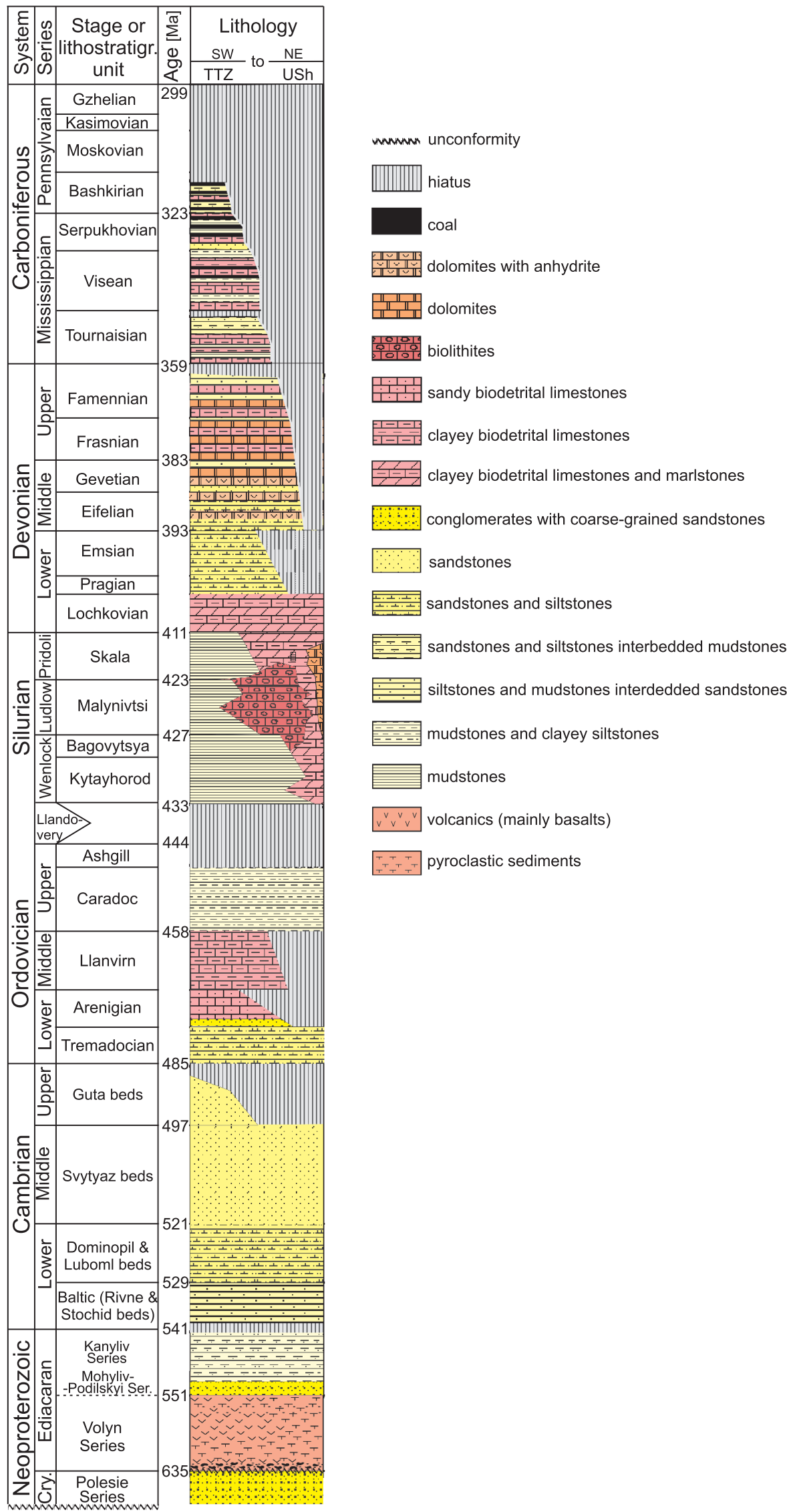

Fig. 2. Lithostratigraphic log of the Neoproterozoic to Carboniferous succession of the southwestern margin of the East European Craton - Volyn-Podillya-Moldavia Basin (after Velikanov et al., 1983; Chebanenko et al., 1990; Shulga et al., 2007)

TTZ - Teisseyre-Tornquist Zone, Ush - Ukrainian shield 


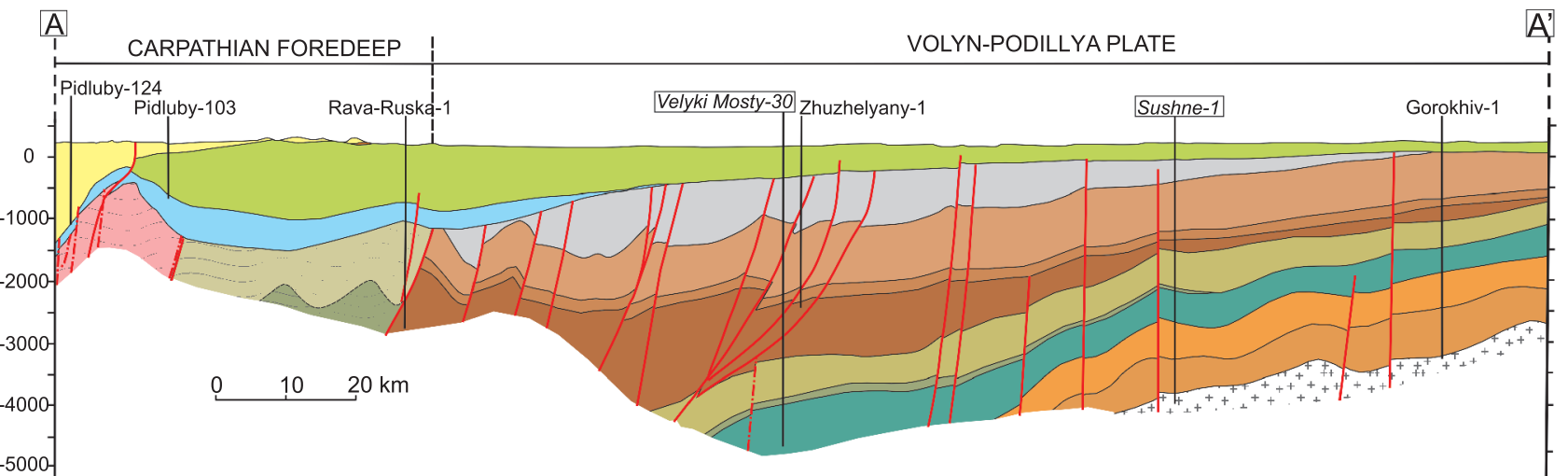

Depth $[\mathrm{m}]$

$$
\begin{aligned}
& \text { Gorokhiv-1 I boult } \\
& \text { Popesti-1 projected borehole }
\end{aligned}
$$
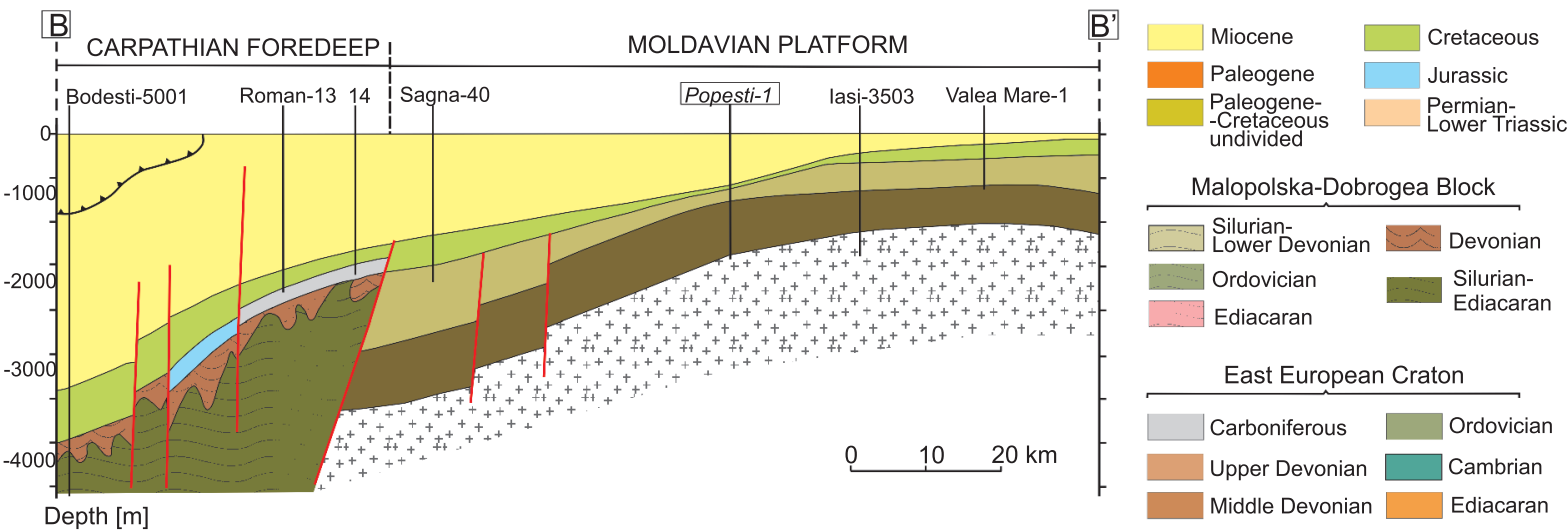

\section{East European Craton}

\begin{tabular}{|l|l|}
\hline Carboniferous & Ordovician \\
\hline Upper Devonian & Cambrian \\
\hline Middle Devonian & Ediacaran \\
\hline Lower Devonian & Ordovician-Ediacaran \\
Devonian & lower-middle \\
undivided & Neoproterozoic \\
\hline Silurian & $+_{++}^{+}$Archean-lower \\
\hline & Proterozoic \\
\hline
\end{tabular}

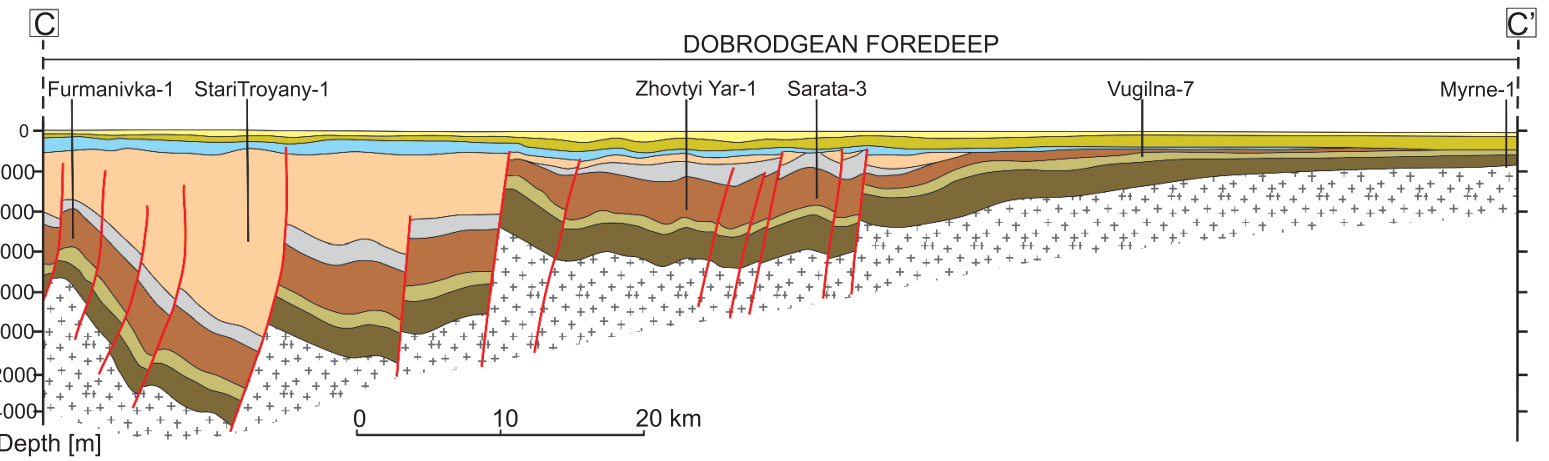

Fig. 3. NE-SW cross-sections illustrating the present-day structural style of the area studied (see Fig. 1 for location) A-A' through the Carpathian Foredeep and the Volyn-Podillya Plate (after Vashchenko et al., 2007, modified); B-B' through the Carpathian Foredeep and the Moldavian Platform (after Patruț and Daneț, 1987, modified); C-C' through the Dobrodgean Foredeep (see Fig. 1 for location) (modified after Gnidets et al., 2002)

Projected boreholes in cross-section A-A': Sushne-1 and Velyki Mosty-1 - projection roughly $17.5 \mathrm{~km}$ and $10 \mathrm{~km}$ from SE respectively; projected boreholes in cross-section B-B': Popesti-1 - projection roughly $13.5 \mathrm{~km}$ from NW

southern parts of the VPMB as the Volyn-Podillya sub-basin (equivalent of the Volyn-Podillya Plate) and the Moldavia-Dobrogea sub-basin (equivalent of the Moldavian Platform and the Dobrogean Foredeep), respectively.

The VPMB accumulated sediments of Neoproterozoic to Paleozoic age (Fig. 2), however, the main focus of the current study is the Ediacaran to Lower Devonian part of the section. The Middle to Upper Devonian deposits were subject to erosion across most of the area analysed, particularly in the area of Moldavian Platform (Fig. 4). The reduced section often limits the ability for effective use of backstripping. Carboniferous and Permian strata are only preserved locally. 


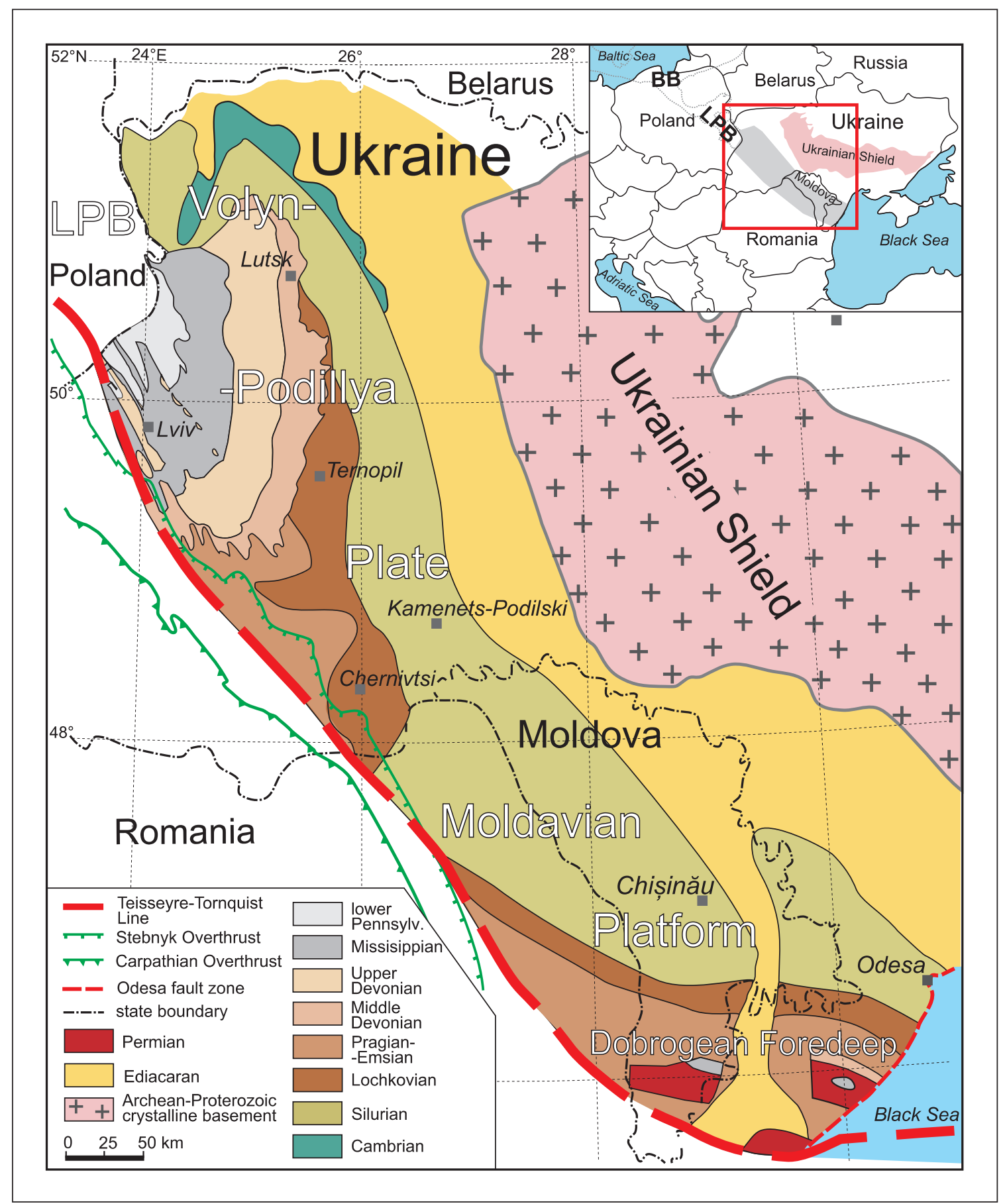

Fig. 4A - location of the study area; B - geological map of the southwestern margin of the East European Craton without the Mesozoic and Cenozoic (modified after Velikanov et al., 1983;

Chebanenko et al., 1990; Gnidets et al., 2002; Shulga et al., 2007)

The structure of the VPMB is shown on three cross-sections: A-A' (Volyn-Podillya Plate), B-B' (Moldavian Platform) and C-C' (Dobrogean Foredeep) (Fig. 3A-C, see Fig. 1 for location), as well as on a geological map without Mesozoic-Cenozoic cover (Fig. 4). A characteristic feature of the Volyn-Podillya Plate is the inclination of Ediacaran-Paleozoic strata towards the west and SW, as well as Variscan tectonic deformation and marked erosion (Fig. 3A). The VPMB is unconformably covered by an undeformed Jurassic and Cretaceous sedimentary cover, and in the SW by the Miocene Carpathian Foredeep. Farther to the SW, the western slope of the EEC is also covered by the Outer Carpathian fold-and-thrust belt.
On the Moldavian Platform, the westward slope of the EEC is less prominent. The Paleozoic strata are partly removed by erosion and are unconformably covered by thick Miocene deposits of the Carpathian Foredeep (Figs. 3B and 4). In the Dobrogean Foredeep, the basement slopes towards the south and SW. The Ediacaran-Paleozoic section in this zone experienced intense Variscan tectonic deformation as well as locally significant uplift and erosion (Figs. 3C and 4). Mesozoic strata cover the Paleozoic deposits unconformably, whereas at the southern limits of the study area the Ediacaran-Paleozoic section is deeply buried beneath deposits filling a Permian-Triassic Trough. 
The sedimentary basins of the SW part of the EEC overlie the Archean-Proterozoic heterogenic crystalline basement, composed of metamorphic and igneous rocks. The basement crops out at the surface within the Ukrainian Shield (Fig. 4) and uniformly dips westward towards the Teisseyre-Tornquist Zone. A maximum thickness of the sedimentary cover reaches $10 \mathrm{~km}$ on the Volyn-Podillya Plate and $7 \mathrm{~km}$ in the Dobrogean Foredeep (Kruglov and Tsypko, 1988; Chebanenko et al., 1990).

The basement is overlain by the Neoproterozoic succession: the Cryogenian continental to marginal marine variegated clastic deposits, lower Ediacaran volcanogenic-terrigenous strata (referred to as the Volyn Series) and the upper Ediacaran conglomerate, passing up section into terrigenous fine-grained deposits (referred to as the Mohyliv-Podilskyi and Kanyliv Series). The Ediacaran strata are unconformably overlain by Cambrian terrigenous sandstone and mudstone, in turn overlain by terrigenous and carbonate Ordovician deposits, locally significantly reduced by erosion (Fig. 2; Gareckij et al., 1987). The Ashgill (Upper Ordovician) and Llandovery (lower Silurian) have not been identified within the study area (Chebanenko et al., 1990; Gerasimov et al., 2006). Wenlock deposits of the lower Silurian rest upon the eroded surfaces of Ordovician, Cambrian and Ediacaran strata. The Silurian strata are represented by clayey, carbonate and carbonate-sulphate rocks, including graptolitic black shales, marlstones, limestones and dolomites with anhydrite interbeds (Radkovets, 2015; Fig. 2).

Up section, the Lochkovian marine mudstone, carbonate and marl are a continuation of Silurian sedimentation within similar depositional environment and similar facies. The upper part of the Lower Devonian, i.e. Pragian-Emsian, covers the Lochkovian strata unconformably. The Pragian and Emsian are composed of terrigenous reddish-brown deposits, which are roughly equivalent to the Old Red Sandstone (Radkovets, 2016). Deposits of the Lower Devonian, unlike the Ediacaran and lower Paleozoic strata, are partly removed by erosion within the Moldavian Platform (Fig. 4).

Clayey-terrigenous and sulphate-carbonate deposits of the Middle and Upper Devonian are significantly eroded within the study area and occur only in its deepest part - the Volyn-Podillya Plate and Dobrogean Foredeep (Chebanenko et al., 1990; Gnidets et al., 2002; Radkovets et al., 2017). The Carboniferous deposits, i.e. Mississippian and Pennsylvanian (Bashkirian) Series, are represented by a coal-bearing terrigenous-carbonate sequence, which is only locally preserved within the Volyn-Podillya Plate and Dobrogean Foredeep, and overlie Devonian strata with an unconformable contact, related to early Carboniferous tectonic deformation and uplift (Gerasimov et al., 2006; Shulga et al., 2007; Fig. 4). Within the study area, Permian-Lower Triassic deposits occur only in the Dobrogean Foredeep where they unconformably cover the Carboniferous and partly the Upper Devonian (Fig. 3C).

The Mesozoic sedimentary succession overlies the eroded surface of Paleozoic and Ediacaran strata (Figs. 3A-C and 4). The Jurassic terrigenous-carbonate rocks within the Volyn-Podillya Plate unconformably cover the truncated surface of mainly Carboniferous deposits, while in the Dobrogean Foredeep these strata rest upon the Lower Triassic and Upper Devonian. A terrigenous-carbonate succession of the Cretaceous extends to the Ukrainian Shield and covers the eroded deposits of the Jurassic, Carboniferous, Devonian, Silurian, Cambrian and Ediacaran.

The Cenozoic of the SW part of the EEC is represented by Paleogene, Neogene and Quaternary strata. The Paleogene, composed of terrigenous deposits, is widespread only in the
Dobrogean Foredeep where it unconformably rests upon Cretaceous strata, whereas within the Volyn-Podillya Plate it occurs only as separate patches. Sulphate-terrigenous-carbonate rocks of the Neogene unconformably cover the Cretaceous deposits. They are widespread within the Moldavian Platform as well as in the Dobrogean and Carpathian foredeeps, while their presence within the Volyn-Podillya Plate is very limited (Chebanenko et al., 1990; Gerasimov et al., 2006).

\section{METHODOLOGY AND DATA}

Twenty-one boreholes in western and SW Ukraine, Moldova and NE Romania were studied using a 1D backstripping approach (see Fig. 1 for location). Tectonic subsidence curves are analysed here with the aim of reconstructing possible tectonic mechanisms governing the basin origin and subsequent development, while the rate of sediment deposition is interpreted in terms of sediment source area activity. The basin analysed evolved significantly in time, both in terms of its geometry and tectonic control on its subsidence, nonetheless, the Ediacaran to Lower Devonian stratigraphic section in the basin lacks unconformities of significant scale, and it is suitable for common subsidence analysis. However, the Middle Devonian to Carboniferous section of the VPMB is far more affected by erosion which decreases the potential of backstripping for this time span.

During backstripping analysis, an isostatic load is removed, and compactional effects are restored (e.g., Angevine et al., 1990). The approach applied here assumes that sedimentary loads were locally compensated according to Airy isostatic principles. The consequences of this assumption for subsidence analysis have been discussed for example by Barton and Wood (1984) and King (1994).

The effects of sediment decompaction during the backstripping procedure are calculated according to the method of Sclater and Christie (1980). The impact of different decompaction algorithms on backstripping results was analysed for the Ediacaran to lower Paleozoic section by Poprawa and Pacześna (2002) directly NW of the study area, i.e. in the Lublin-Podlasie Basin, who concluded that uncertainties related to decompaction methods do not impact the interpretation of tectonic subsidence curves significantly.

Numerical ages for the upper and lower limits of the individual stratigraphic units were adopted according to the Cohen et al. (2013) chronostratigraphic chart. The sensitivity of tectonic subsidence analysis to uncertainties in the geochronological definition of individual stratigraphic units was also analysed by Poprawa and Pacześna (2002) in the nearby Ediacaran-lower Paleozoic Lublin-Podlasie Basin with the use of alternative chronostratigraphic charts. The study demonstrated that in this case possible error bars of the numerical ages as well as inconsistency between alternative chronostratigraphic charts do not affect results of backstripping considerably.

Changes in the palaeobathymetry of the basin over time were also included in calculations. The palaeobathymetry was tentatively quantified based on facies constraints. Fluctuations in bathymetry over time of the mostly shallow marine environment were limited compared to a coeval increase in thickness of the sedimentary section. As a consequence, uncertainties related to palaeobathymetry restoration do not have a significant impact on the results obtained. The backstripping calculations were performed using BasinMod 1D software.

The backstripping results are sensitive to uncertainties in the stratigraphic division of the section. In the area analysed, 
there are some controversies with regard to the stratigraphy of the Neoproterozoic succession. Here, we define the Neoproterozoic volcanogenic and clastic rocks of the Volyn Series as lower Ediacaran (Fig. 2) based on radiometric geochronology of their lateral equivalents in the Orsha-Volyn Aulacogen, including also the northern Volyn region and Lublin Basin. The age of volcanogenic rocks in these regions is documented by: U-Pb dating on zircon $-551 \pm 4 \mathrm{Ma}$ (Compston et al., 1995), 576 $\pm 14 \mathrm{Ma}$ (Shumlyanskyy and Andréasson, 2004; Shumlyanskyy et al., 2007) and $571 \pm 13$ and $573 \pm 14 \mathrm{Ma}$ (Shumlyanskyy et al., $2016) ;{ }^{40} \mathrm{Ar} /{ }^{39} \mathrm{Ar}$ dating on whole rock - 580-590 Ma (Elming et al., 2007); and K/Ar dating on whole rock of significantly lower precision than the previous methods - 540-600 Ma (Velikanov and Korenchuk, 1997), 590-625 Ma (Sokolov and Fedonkin, 1990) and $560 \mathrm{Ma}$ (Savchenko et al., 1984). Note that such a stratigraphic definition of the Volyn Series, in the older nomenclature assigned to the Lower Vendian (e.g., Gareckij et al., 1987 ), is not unanimously accepted since the series was also alternatively assigned to the Cryogenian (e.g., Kosakowski et al., 2017). A consequence of the approach presented is that the overlying conglomerate and terrigenous fine-grained deposits of the Mohyliv-Podilskyi and Kanyliv Series represent the uppermost part of the Ediacaran (541-551 Ma; Fig. 2), while in the previous literature they were often attributed to the whole Ediacaran (e.g., Kosakowski et al., 2017) or Upper Vendian and Valday (Gareckij et al., 1987).

Particularly problematic is the stratigraphic division of the Precambrian sedimentary section in borehole Lyman-1. In this borehole, beneath Cambrian strata, a succession of $509 \mathrm{~m}$ of upper Ediacaran deposits is distinguished. However, deeper in the borehole section there is $944 \mathrm{~m}$ of sandstones with no proper stratigraphic constraints, still not pierced by drilling entirely. In the current study, this succession is tentatively assigned to the Polesie Series based on facies correlation, the age of which was traditionally regarded as Riphean (e.g., Gareckij et al., 1987), though it is reinterpreted as Cryogenian in this paper.

Another important stratigraphic issue comprises uncertainties with regard to the position of the boundary between the lower and middle Cambrian, resulting in an uncertain position of a section with a thickness from a few tens to a few hundred metres, depending on the location. Within the lower part of the lower Cambrian succession of the VPMB, the Baltic stage is distinguished, which includes the Rivne and Stochid beds (Fig. 2). As to the remaining part of the Cambrian succession, its stratigraphic subdivision is still not well-defined. These rocks are tentatively ascribed to the upper part of the lower Cambrian and the middle-upper Cambrian being attributed to the Berezhtsi stage (Vishnyakov et al., 1981). The latter is subdivided into the Dominopil and Luboml beds, both representing the upper part of the lower Cambrian, the middle Cambrian Svytyaz beds and the upper Cambrian Guta beds (Fig. 2). In most of the boreholes studied, the boundaries of individual beds within the Berezhtsi stage require additional stratigraphic studies to be precisely constrained.

A similar issue affects the position of the boundary between the Wenlock and Ludlow. In this case, an uncertain stratigraphic classification concerns a section a few tens of metres thick (mainly the Bagovytsys Formation). In the current study, the Bagovytsys Formation was included into the Ludlow Series (Radkovets, 2015).

\section{RESULTS}

A tectonic subsidence history and sedimentation rate changes over time were reconstructed for 21 representative boreholes from the Ediacaran-Paleozoic VPMB (see Fig. 1 for location). The boreholes were selected for analysis so as to penetrate the most complete Ediacaran-lower Paleozoic-Lower Devonian section possible. Their stratigraphy and lithology are relatively well-studied and defined and the boreholes are spread across the basin in a generally regular grid. The results of the calculations, i.e. tectonic subsidence curves and sedimentation rate diagrams, are shown in Figure 5. Tectonic subsidence patterns are consistent throughout the basin for the time period studied.

The development of the VPMB commenced with an event of relatively rapid tectonic subsidence in the latest Ediacaran, which was followed by a systematically decreasing rate of subsidence during the Cambrian and Ordovician (Fig. 5). This process is clearly visible in boreholes located in close proximity to the western margin of the EEC, as well as in boreholes penetrating the entire Cambrian and Ediacaran section. Examples are the boreholes Peremyshlyany 1, Litovyzh 1, Zalozhtsi 1, Buchach 3, Kolynkiv 1, Chernivitsi 1, Sagna 40, PopestiUngheni 59, lasi 3503, Lyman 1 (Fig. 5). There is a systematic decrease in sedimentation rate observed at each location from the late Ediacaran throughout the Cambrian and Ordovician. In the western and SW parts of the area analysed, deposition rate declines throughout this time span in most cases from 45-75 to 2-10 m/My (Fig. 5).

Towards the east and NE, i.e. away from the EEC margin, the pattern of tectonic subsidence rate decreases in time throughout the Ediacaran, Cambrian and Ordovician and is less prominent. The thickness of the Ediacaran as well as the lower Cambrian section is significantly lower compared to the zone located closer to the EEC margin (e.g., boreholes: Volodymyr Volynskyi 1, Kremenets 1, 17653, Valea Mare 1, Kesheneu 1, Myrne 1, Balaban 1; Fig. 5). The effects of the syn-rift phase of subsidence and subsequent post-rift thermal sag cannot be effectively investigated in boreholes, which did not entirely penetrate the Ediacaran and/or Cambrian. This is particularly true for boreholes Krekhiv 1, Dublyany 4, Zagaypil 1 and Valea Mare 1.

The overall development of tectonic subsidence of the VPMB during the latest Ediacaran to Ordovician is characteristic of the thermal sag of rifted basins, where a syn-rift phase is expressed by rapid tectonic subsidence, mainly within tectonic extensional grabens, whereas subsequent post-rift basin development is governed by cooling of the lithosphere resulting in a systematically decreasing tectonic subsidence rate coeval with the lateral expansion of the basin (e.g., McKenzie, 1978). In the case of the VPMB, this concept indicates the presence of rift-related extension in the basin during late Ediacaran time, which is independently supported by the emplacement of rift-related volcanic lavas directly prior to and at the time of syn-rift sediment deposition (see Fig. 6A for the lateral extent of the upper Ediacaran volcanoclastic rocks). The pattern of syn-rift to post-rift subsidence is better developed in the SW part of every unit included in the study: Volyn-Podillya Plate, Moldavian Platform and Dobrogean Foredeep (Fig. 5). The late Ediacaran and Cambrian rate of tectonic subsidence and the total thickness of corresponding strata also increases in the same direction (Figs. 5 and $6 B, C)$. This indicates that the main rift zone developed at the SW margin of the EEC.

The post-rift thermal sag pattern of tectonic subsidence is to some extent obscured by late Cambrian (to earliest Ordovician?) erosion, which locally removed the whole middle and upper Cambrian section (see the lateral extent of erosion in Fig. $6 \mathrm{C})$, resulting in a significant stratigraphic gap in some of the boreholes analysed. Therefore, the boreholes most reliable for the Ediacaran to Ordovician subsidence mechanism reconstruction are those with a middle and upper Cambrian section preserved. The most complete sections occur in boreholes 


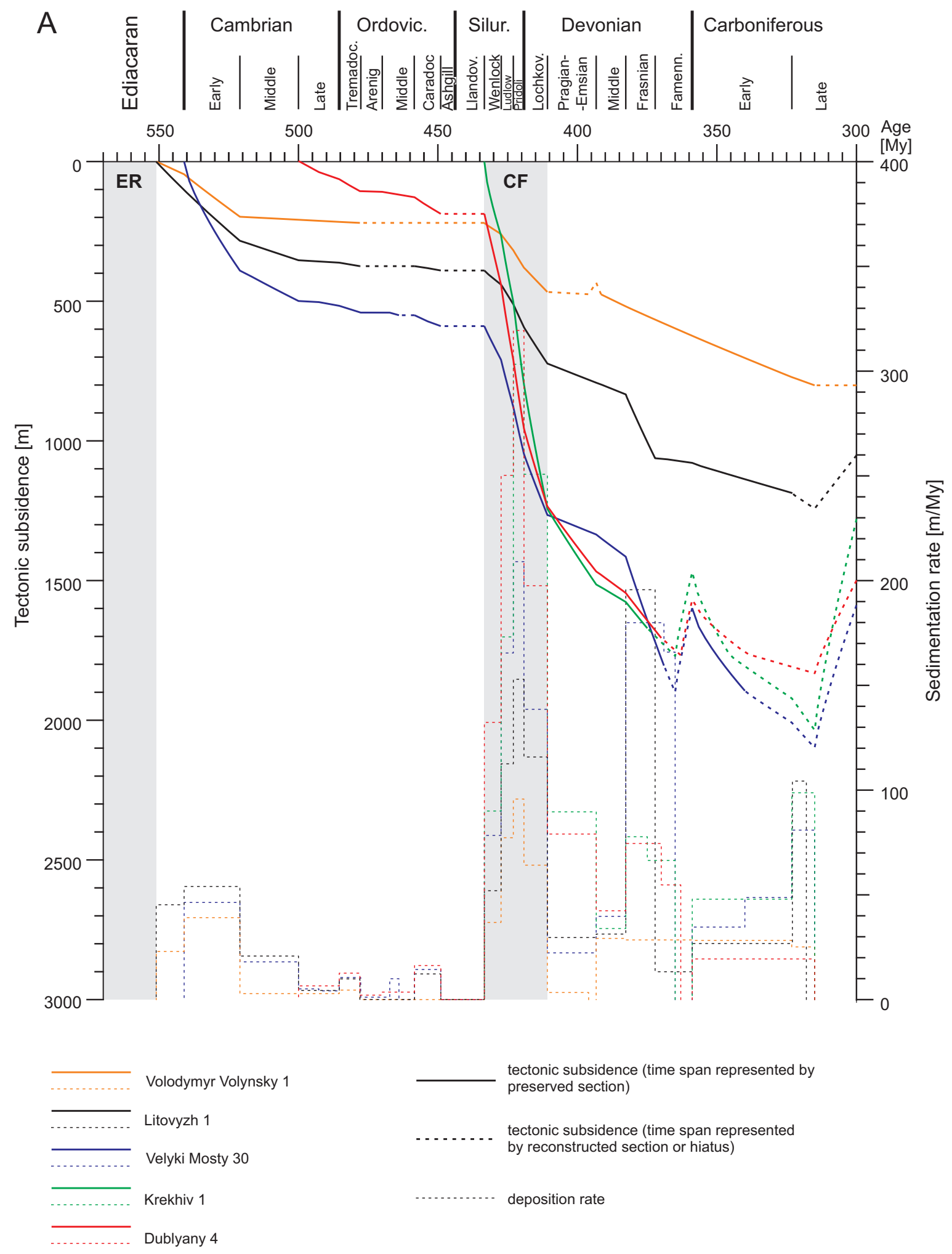

Fig. 5A - results of backstripping: tectonic subsidence curves and sedimentation rate diagrams for 21 boreholes from the Volyn-Podillya-Moldavia Basin (ER - Ediacaran rifting, locally with rift-related magmatic activity, CF - Caledonian foredeep)

Northwestern part of the Volyn-Podillya Plate

(boreholes: Volodymyr Volynskyi 1, Litovyzh 1, Velyki Mosty 30, Krekhiv 1, Dublyany 4) 


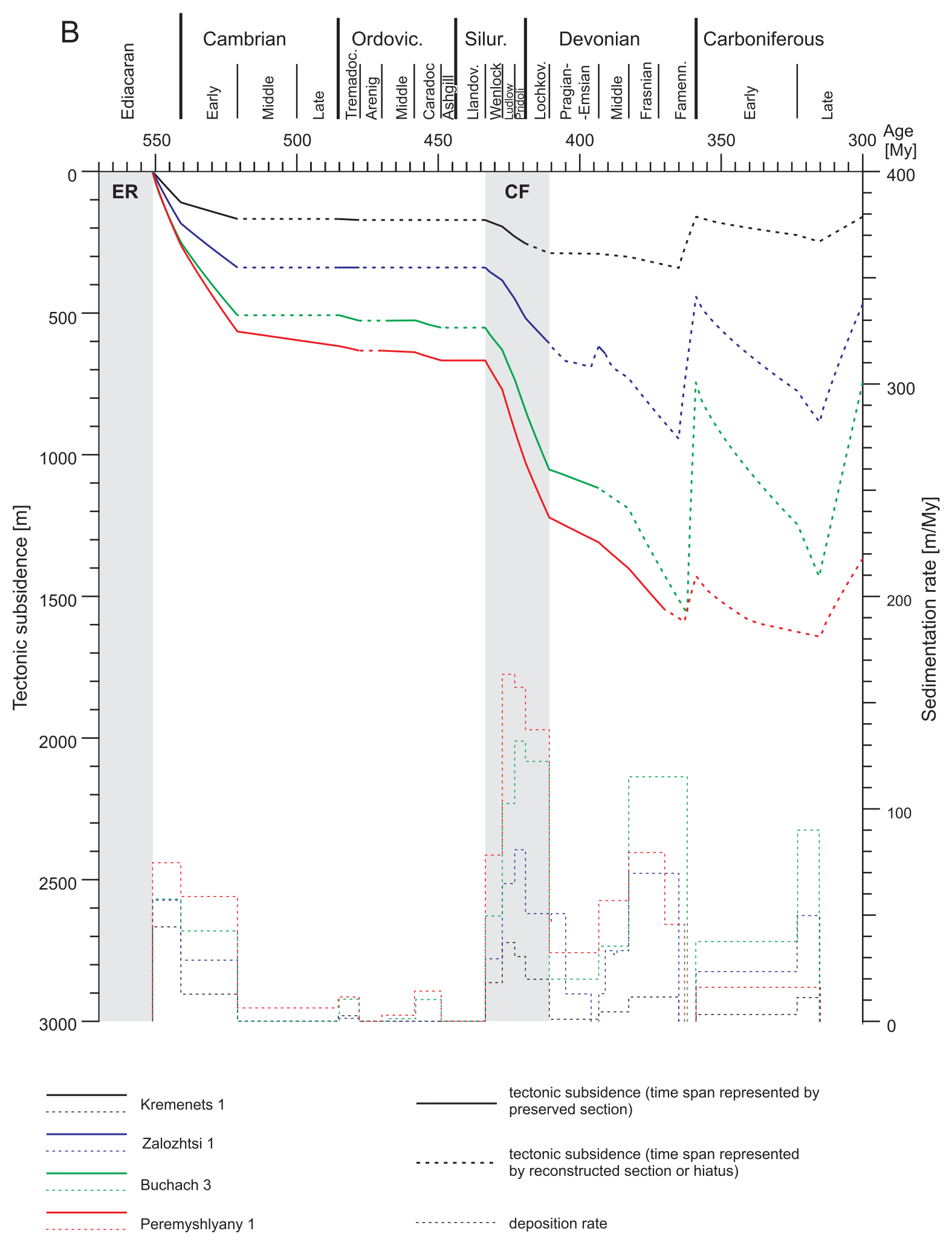

Fig. 5B - results of backstripping: tectonic subsidence curves and sedimentation rate diagrams for $\mathbf{2 1}$ boreholes from the Volyn-Podillya-Moldavia Basin (ER - Ediacaran rifting, locally with rift-related magmatic activity, CF - Caledonian foredeep)

Central part of the Volyn-Podillya Plate (boreholes: Kremenets 1, Zalozhtsi 1, Buchach 3, Peremyshlyany 1) 


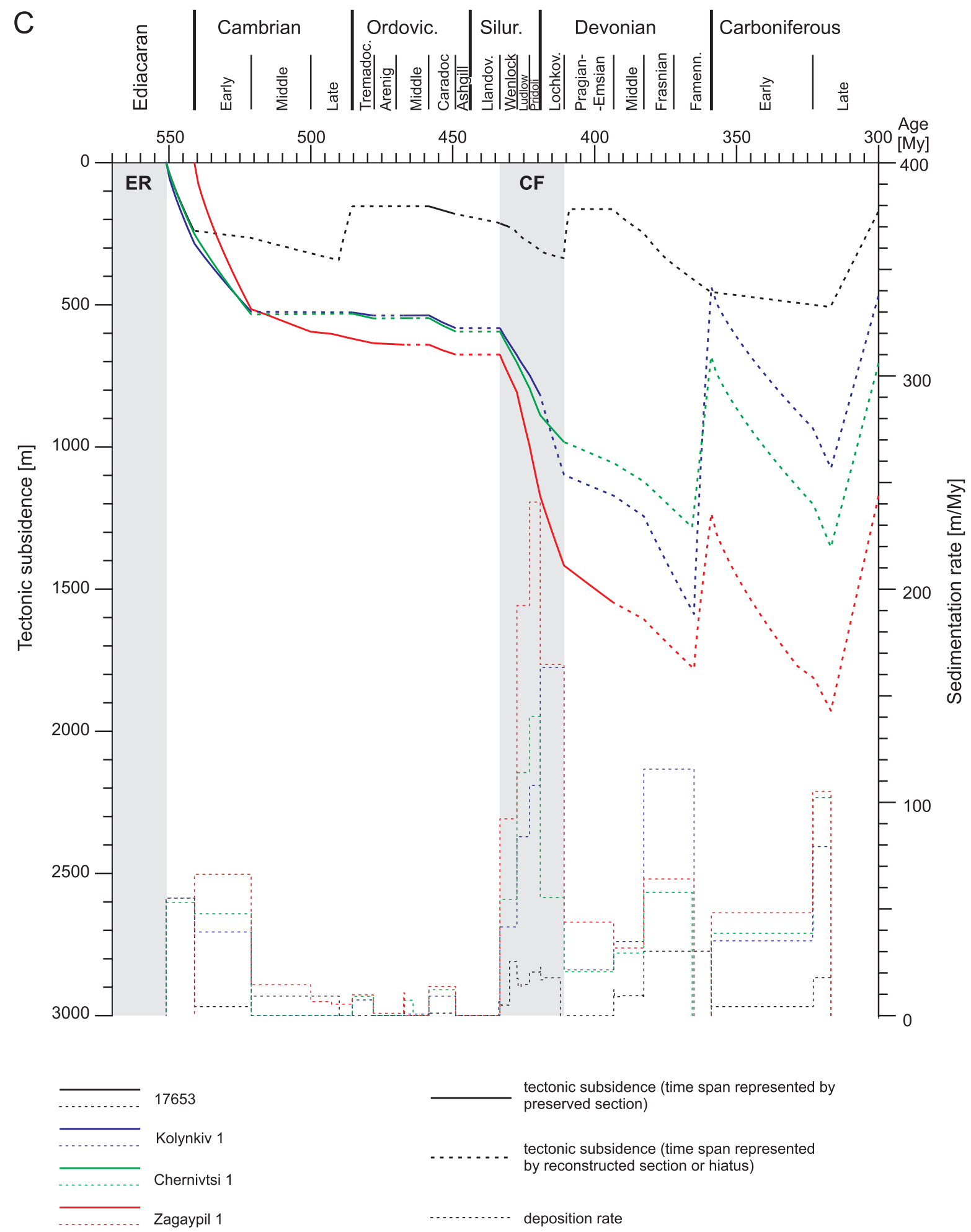

Fig. 5C - results of backstripping: tectonic subsidence curves and sedimentation rate diagrams for 21 boreholes from the Volyn-Podillya-Moldavia Basin (ER - Ediacaran rifting, locally with rift-related magmatic activity, CF - Caledonian foredeep)

Southern part of the Volyn-Podillya Plate (boreholes: 17653, Kolynkiv 1, Chernivitsi 1, Zagaypil 1) 


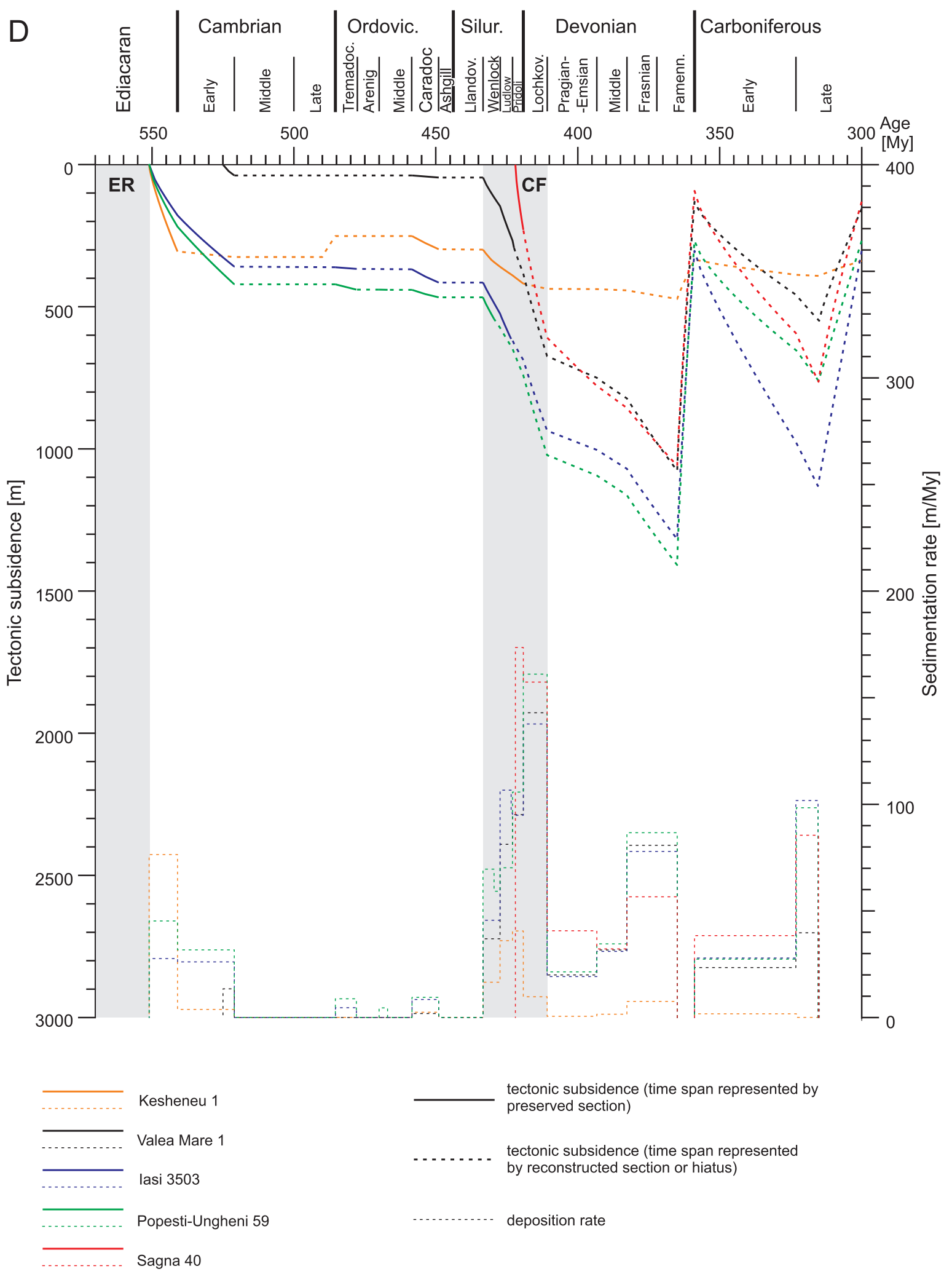

Fig. 5D - results of backstripping: tectonic subsidence curves and sedimentation rate diagrams for 21 boreholes from the Volyn-Podillya-Moldavia Basin (ER - Ediacaran rifting, locally with rift-related magmatic activity, CF - Caledonian foredeep) 


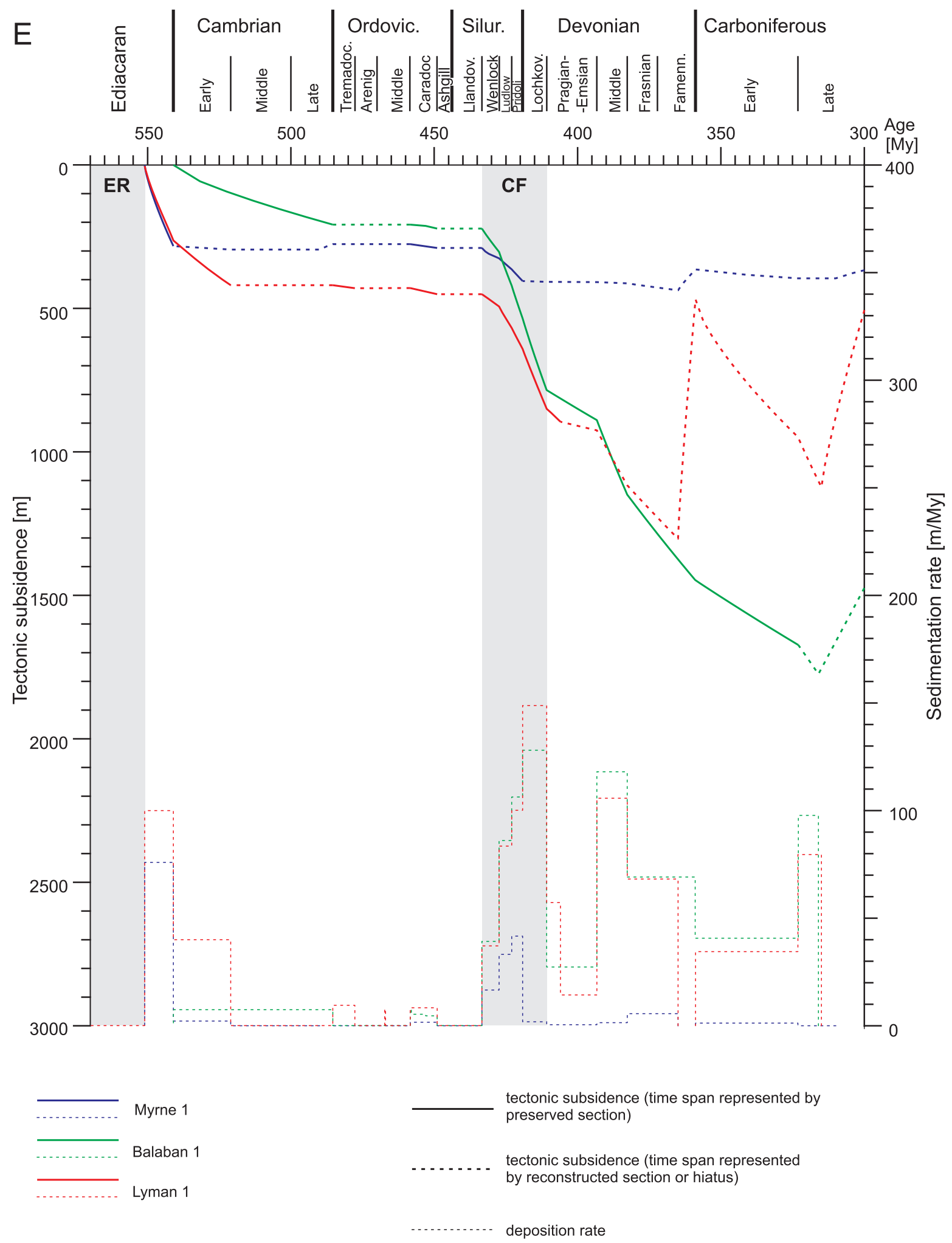

Fig. 5E - results of backstripping: tectonic subsidence curves and sedimentation rate diagrams for 21 boreholes from the Volyn-Podillya-Moldavia Basin (ER - Ediacaran rifting, locally with rift-related magmatic activity, CF - Caledonian foredeep)

Dobrodgean Foredeep (boreholes: Myrne 1, Balaban 1, Lyman 1) 
Litovyzh 1, Volodymyr Volynskyi 1, Velyki Mosty 30, Peremyshlyany 1 and Zagaypil 1, where a pattern of subsidence decaying over time is well-documented (Fig. 5A-C).

The lower Ediacaran volcanoclastic succession (Volyn Series), the emplacement of which is coeval in time with the initial phase of syn-rift subsidence, is present in the northern and western parts of the Volyn-Podillya sub-basin and its thickness increases towards the north and NW (Fig. 6A). Lateral thickness changes of this formation are, however, difficult to constrain in detail since several of the boreholes analysed did not penetrate the entire Ediacaran section. The maximum thickness of the volcanoclastic Volyn Series reaches $483 \mathrm{~m}$ at the NW limits of the area analysed (borehole Volodymyr Volynskyi 1; Fig. 6A). An association of this rift-related magmatic activity with the Orsha-Volyn Aulacogen as well as with its intersection with the Peri-Tornquist system of basins at the SW margin of the EEC seems to be well-documented (Gareckij et al., 1987; Poprawa and Pacześna, 2002).

The upper part of the Ediacaran section, composed of clastic deposits (the Mohyliv-Podilskyi and Kanyliv Series), is characterized by a significant lateral increase in thickness. In the case of the Volyn-Podillya sub-basin, the thickness increases from NE to SW to a maximum of $330 \mathrm{~m}$ (borehole Peremyshlyany 1) and in the Moldavia-Dobrogea sub-basin from the north to the south and SW to a maximum of $509 \mathrm{~m}$ (borehole Lyman 1) (Fig. 6B). Maximum late Ediacaran sedimentation rates in the Volyn-Podillya sub-basin are in the range of 45-75 m/My (e.g., boreholes Litovyzh 1, Peremyshlyany 1 , Buchach 1, Zalozhtsi 1, Chernivitsi 1, Kolynkiv 1; Fig. 5A-C), whereas in the Moldavia-Dobrogea sub-basin, sedimentation rates reach 45-100 m/My (boreholes Kesheneu 1, Lyman 1, Myrne 1; Fig. 5D-E).

A similar lateral trend of thickness and deposition rate changes is observed in the lower Cambrian succession (Stochid, Rivne, Luboml and Dominopil beds). The lower Cambrian section in the Moldavia-Dobrogea sub-basin increases in thickness from the north to south to $389 \mathrm{~m}$ in the Lyman 1 borehole and to the SW to $300 \mathrm{~m}$ in the Popesti-Ungheni 59 borehole (Fig. 6C). The lower Cambrian sedimentation rate is 40 and $32 \mathrm{~m} /$ My respectively in these boreholes (Fig. 5D, E). In the Volyn-Podillya sub-basin, strata of this age increase in thickness towards the west and SW (Fig. 6C). The thickness of the lower Cambrian in the Peremyshlyany 1 borehole is $531 \mathrm{~m}$, while in the Zagaypil 1 borehole it exceeds $618 \mathrm{~m}$ (section of the lower Cambrian not penetrated entirely). The early Cambrian sedimentation rate in the boreholes is 58 and $68 \mathrm{~m} / \mathrm{My}$ respectively (Fig. 5B, C). The middle Cambrian sedimentation rates in the Volyn-Podillya and the Moldavia-Dobrogea sub-basins are lower and reach a maximum of 15-20 and 8-10 m/My, respectively (Fig. 5A-C).

The thickness of the middle and upper Cambrian successions is difficult to constrain in the VPMB due to the latest Cambrian (to earliest Ordovician?) erosion, the lateral extent of which is shown in Figure 6C. The boreholes with the best-preserved Cambrian section, i.e. Velyki Mosty 30, Litovyzh 1, and Zagaypil 1 (Volyn-Podillya sub-basin), documented thicknesses of the middle Cambrian (Svytyaz beds) of $170 \mathrm{~m}, 149 \mathrm{~m}$ and $140 \mathrm{~m}$, respectively. The thickness of the upper Cambrian (Guta beds) in the same boreholes ranges between 20 and $40 \mathrm{~m}$, though is partly reduced by erosion.

During the Ordovician, tectonic subsidence in the VPMB was very low (Fig. 5), and hiatuses are common in the borehole sections. The thickness of the Ordovician in the Volyn-Podillya sub-basin typically ranges between 65 and $115 \mathrm{~m}$, reaching a maximum of $130 \mathrm{~m}$ in the Dublyany 4 borehole. In the Moldavia-Dobrogea sub-basin, Ordovician deposits are gener- ally of lower thickness reaching a maximum of $86 \mathrm{~m}$ (borehole Lyman 1). Ordovician sedimentation rates in the basin studied are very low, mostly $<10 \mathrm{~m} / \mathrm{My}$ (Fig. 5). A major thickness component of the Ordovician section is the Caradoc, which further to the NW in the Lublin-Podlasie and Baltic Basins corresponds to a time of initial development of the Caledonian foredeep basin (Poprawa et al., 1999; Poprawa, 2006b). In the VPMB, the thickness of Caradoc marls increases towards the SW margin of the EEC to roughly $50-60 \mathrm{~m}$ and $30-40 \mathrm{~m}$ in the Volyn-Podillya and the Moldavia-Dobrogea sub-basins, respectively (Fig. 6D). This is followed by the Ashgill hiatus, which was presumably related to falling global sea level.

Beginning with the Wenlock, a significant change in subsidence pattern compared to the Ediacaran-Ordovician is observed across the whole VPMB. Following the Landovery hiatus, tectonic subsidence began to increase in rate systematically from Wenlock to Early Devonian (Lochkovian) time, creating subsidence curves with convex shapes that are typical of foreland basin development (Fig. 5). The amount of tectonic subsidence calculated for the Wenlock is a combined effect of the increase in sediments thickness as well as of the increase in palaeosea depth by few tens of metres. For the whole Wenlock to Lochkovian stage of basin development, a high tectonic subsidence rate is characteristic, particularly in its SW and western parts.

The Wenlock deposits increase their thickness from the east and NE, where they meet their erosional limit, towards the SW and reach a maximum of $\sim 300 \mathrm{~m}$ and $100-200 \mathrm{~m}$ in the NW and SW part of the area studied, respectively (Fig. 6E). Very similar lateral thickness changes characterize the Ludlow, which reaches its maximum thickness of up to $500 \mathrm{~m}$ in the Volyn-Podillya sub-basin and $150 \mathrm{~m}$ in the Moldavia-Dobrogea sub-basin (Fig. 6F). The same trend continues into the Pridoli, where the maximum thickness in the NW and SW part of the study area is roughly $600 \mathrm{~m}$ and $150-200 \mathrm{~m}$, respectively (Fig. $6 \mathrm{G})$. In the Moldavian zone of the basin, the thickness of the Silurian is partly reduced by erosion, especially its upper section including the Ludlow and Pridoli. Throughout the entire Wenlock-Pridoli time span, the VPMB developed as a flexure of the western slope of the EEC inclined towards the SW, i.e. towards the craton margin. During the Silurian, the amount of subsidence along the SW margin of the basin decreased laterally from the NW to SE (Fig. 6E-G).

Across the major part of the basin, the pattern of rapid subsidence typical of the Caledonian foredeep continued up to the Lochkovian (Fig. 5). In terms of facies development and sedimentary environment, the Lochkovian deposition is a continuation of late Silurian sedimentation being dominated by marine marl and mudstone (Ratkovets, 2016). Lateral thickness changes of the Lochkovian deposits are significantly affected by post-depositional uplift and erosion, particularly in the Moldavia-Dobrogea sub-basin (Fig. 6H). Nonetheless, the westward and southward slope of basin floor was still well-developed during this time. The maximum thickness of the Lochkovian in the Volyn-Podillya and the Moldava-Dobrogea sub-basins ranges between 1100 and $700 \mathrm{~m}$, respectively (Fig. $6 \mathrm{H}$ ). Therefore, the Silurian flexural foredeep basin continued to develop during the Lochkovian, though the foredeep became narrower and the contrast between the eastern and NE zone with limited subsidence and the SW zone with very rapid subsidence is higher than previously.

During the Silurian-Lochkovian stage of basin development, a significant increase in sedimentation rate compared to the Ediacaran, Cambrian and Ordovician is observed in the SW part of the basin, being a zone of mostly open shelf mudstone deposition. In the Volyn-Podillya part of that zone, the Wenlock 


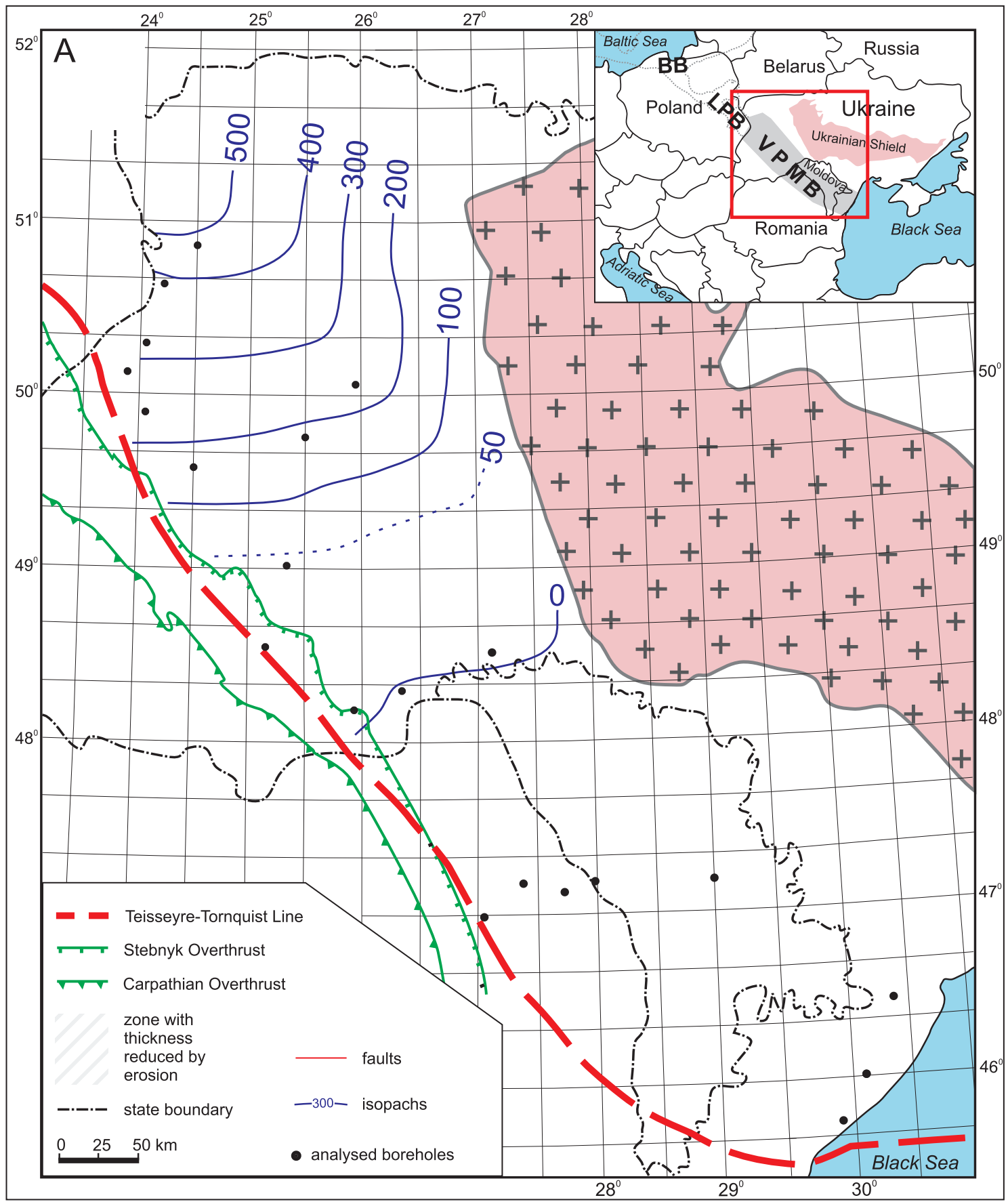

Fig. 6A - thickness maps for the following stratigraphic and lithostratigraphic units of the Volyn-Podillya-Moldavia Basin

Lower Ediacaran, Volyn Series

sedimentation rate ranged between $80-130 \mathrm{~m} / \mathrm{My}$ with the highest values noted for the NW part of the mudstone deposition zone (Dublyany 4 borehole; Fig. 5A-C). Lower sedimentation rates are calculated for the Wenlock in the SW part of the Moldavia-Dobrogea sub-basin, where they are typically in the range of $40-80 \mathrm{~m} / \mathrm{My}$ (Fig. 5D, E). A general increase of sedimentation rate from the Wenlock to the late Silurian is observed in every location. In the western Volyn-Podillya sub-basin, the highest sedimentation rates for the Ludlow and Pridoli are similar in range, being 170-250 m/My and 210-320 m/My, respec- tively (Fig. 5A-C). In the SW part of the Moldavian Platform and Dobrogean Foredeep, sedimentation rates of the Ludlow-Pridoli deposits are lower and range between 80-10 m/My and 100-160 m/My, respectively (Fig. 5D, E).

The Lochkovian marls in the SW part of the Volyn-Podillya sub-basin are characterized by a slight decrease in deposition rate compared to the Silurian, with a maximum depositional rate of $120-250 \mathrm{~m} / \mathrm{My}$ identified in the Krekhiv 1 borehole (Fig. $5 \mathrm{~A}-\mathrm{C})$. Lochkovian sedimentation rates in the Moldavia-Dobrogea sub-basin are generally lower compared to the Volyn- 


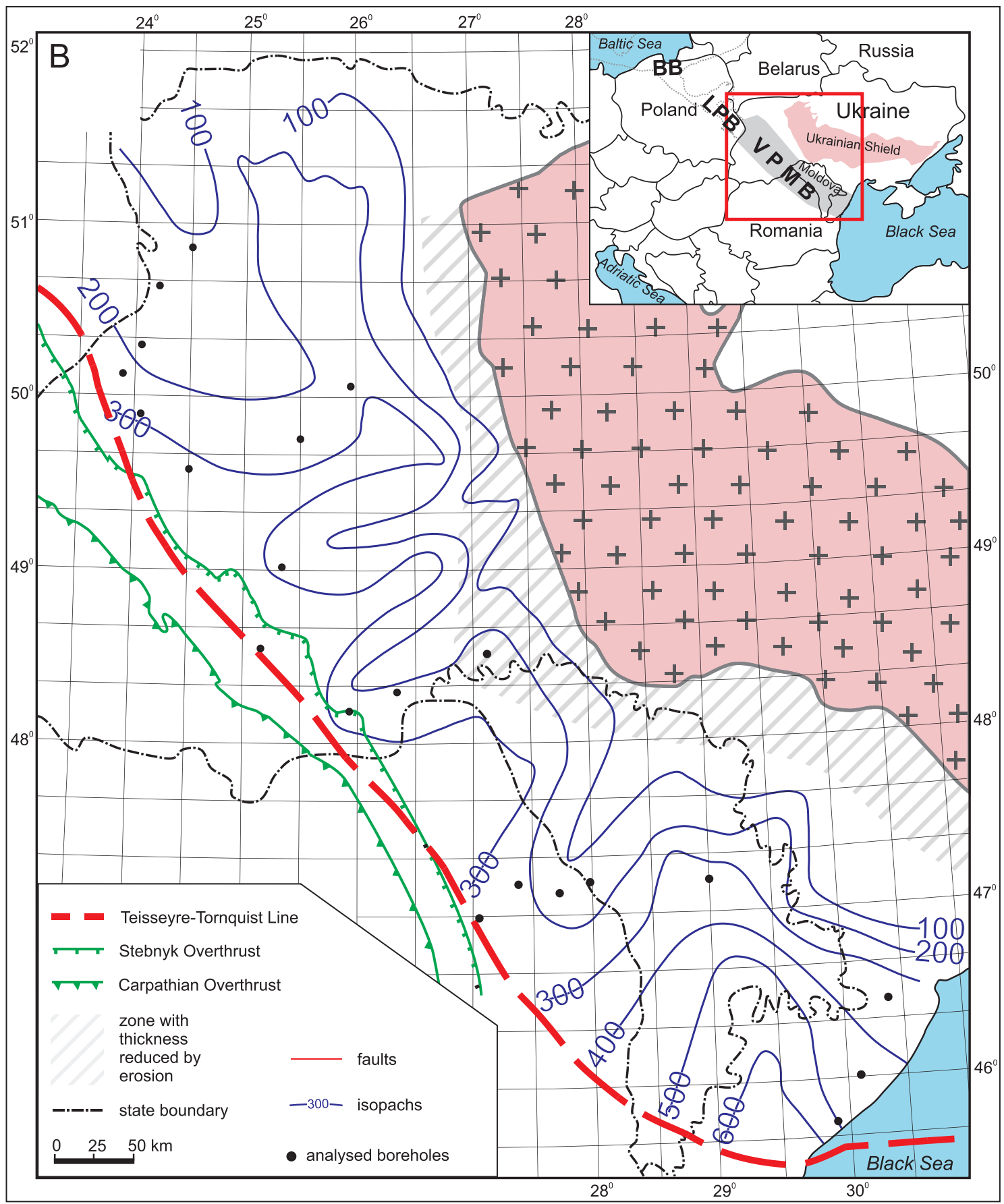

Fig. 6B - thickness maps for the following stratigraphic and lithostratigraphic units of the Volyn-Podillya-Moldavia Basin

Upper Ediacaran, Mohyliv-Podilskyi and Kanyliv Series (after Kosakowski et al., 2017; Radkovets et al., 2018, though note the difference in stratigraphic designation of these series in the original and current paper)

-Podillya sub-basin and maximum values of 150-160 m/My are observed in the Lyman 1 borehole. In most of the analysed boreholes located in the Moldavia-Dobrogea sub-basin the Lochkovian sedimentation rates are higher than in the Silurian (Fig. 5D, E).

Between the Pragian and Emsian, significant changes are observed in the VPMB development. A decrease in the rate of tectonic subsidence is identified throughout the entire basin analysed (Fig. 5). The marine marl facies were replaced by terrigenous Old Red clastics of reddish colour which were supplied mostly from the north and NE (Radkovets, 2016). Over a significant part of the study area, Pragian-Emsian sediments were removed by erosion, particularly on the Moldavian Platform and in eastern Podillya. Nonetheless, the preserved part of the section is characterized by a westward dip of strata in the Volyn-Podillya sub-basin with a maximum thickness at the western margin of the EEC of roughly $800 \mathrm{~m}$ (Fig. 6I). In the southern Moldavia-Dobrogea sub-basin, the Pragian-Emsian 


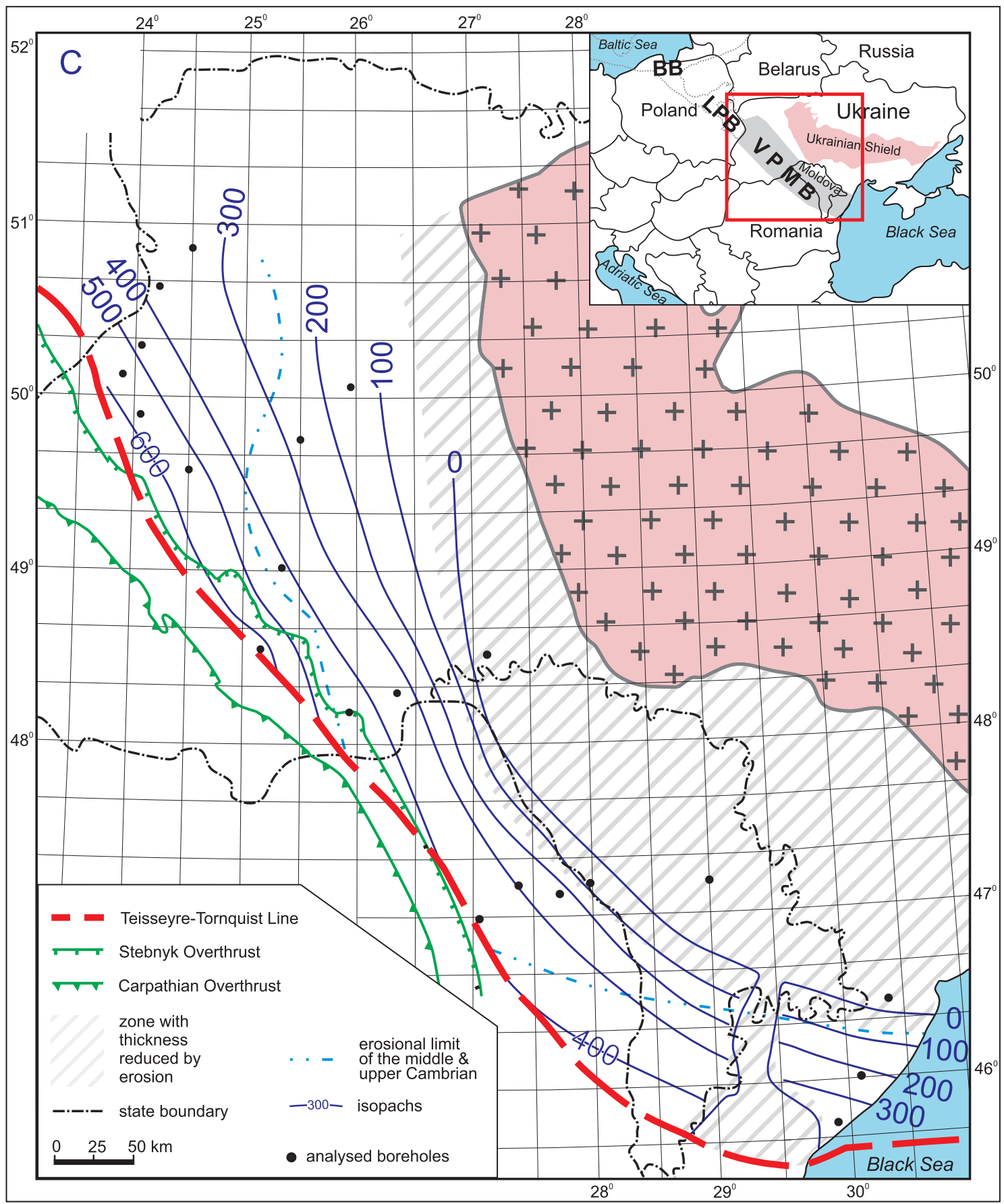

Fig. 6C - thickness maps for the following stratigraphic and lithostratigraphic units of the Volyn-Podillya-Moldavia Basin

Lower Cambrian, Rivne, Stochid, Luboml and Dominopil beds

succession reaches its maximum thickness of $>300 \mathrm{~m}$ at the southern limit of the basin (Fig. 6I). The Pragian-Emsian sedimentation rates were significantly lower than those during the Silurian and Lochkovian. In the SW part of the Volyn-Podillya sub-basin and in the Moldavia-Dobrogea sub-basin, they reach maximum values of $80-90 \mathrm{~m} / \mathrm{My}$ and $15-30 \mathrm{~m} / \mathrm{My}$, respectively (Fig. 5). During the Pragian-Emsian, the VPMB belonged to the post-collisional Old Red basin system, with subsidence presumably governed by lithospheric isostatic imbalance which was caused by the Caledonian collision and the development of an accretionary wedge.
The occurrence of the Middle and Upper Devonian as well as Carboniferous deposits in the VPMB is limited to the western part of the Volyn-Podillya Plate (boreholes Volodymyr Volunskyi 1, Velyki Mosty 30, Litovyzh 1, Krekhiv 1, Dublyany 4, Peremyshlyany 1), as well as to a very limited area in the Dobrogean zone in the vicinity of the Balaban 1 borehole (Fig. 4). Tectonic subsidence analysis of the Middle and Upper Devonian to Carboniferous phase of VPMB evolution was limited to these boreholes, since in the remaining cases uncertainties during the reconstruction of the missing section are too high to consider the backstripping results for this time span reliable. 


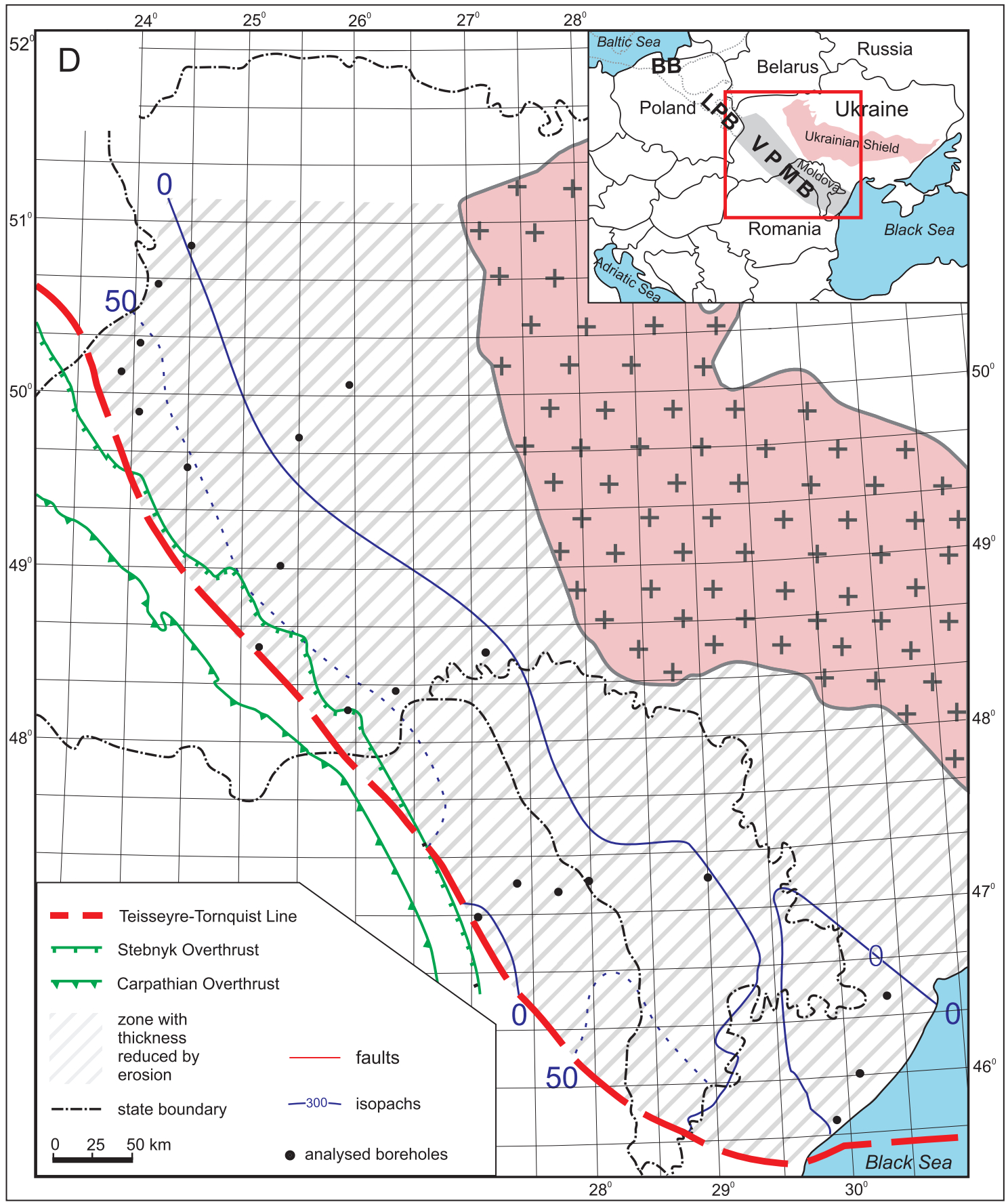

Fig. 6D - thickness maps for the following stratigraphic and lithostratigraphic units of the Volyn-Podillya-Moldavia Basin

Caradoc

Backstripping of the Balaban 1 borehole section reveals rapid subsidence throughout the time span considered, with phases of subsidence acceleration in the Middle Devonian followed by a slight decrease in subsidence rate (Fig. 5E). The shape of the tectonic subsidence curve does not have any features allowing for a conclusive subsidence mechanism determination. Sedimentation rate at this location is relatively high for the time span considered and is $\sim 120 \mathrm{~m} / \mathrm{My}$ for the Middle Devonian, $70 \mathrm{~m} /$ My for the Frasnian and Famennian, and $40 \mathrm{~m} / \mathrm{My}$ for the early Carboniferous (Fig. 5E).
On the western part of the Volyn-Podillya Plate, most of the boreholes analysed display a continual tectonic subsidence during the Middle to Late Devonian with local phases of its significant acceleration observed in the Frasnian (e.g., boreholes Velyki Mosty 30, Litovyzh 1, Peremyshlyany 1; Fig. 5A, B). Such short-term phases of rapid subsidence in small depocentres suggest a transtensional tectonic regime. The thickness of the Middle Devonian succession in this zone increases towards the $\mathrm{W}$ and SW and obtains its maximum value of $323 \mathrm{~m}$ in the Peremyshlyany 1 borehole (Fig. 6J). The highest 


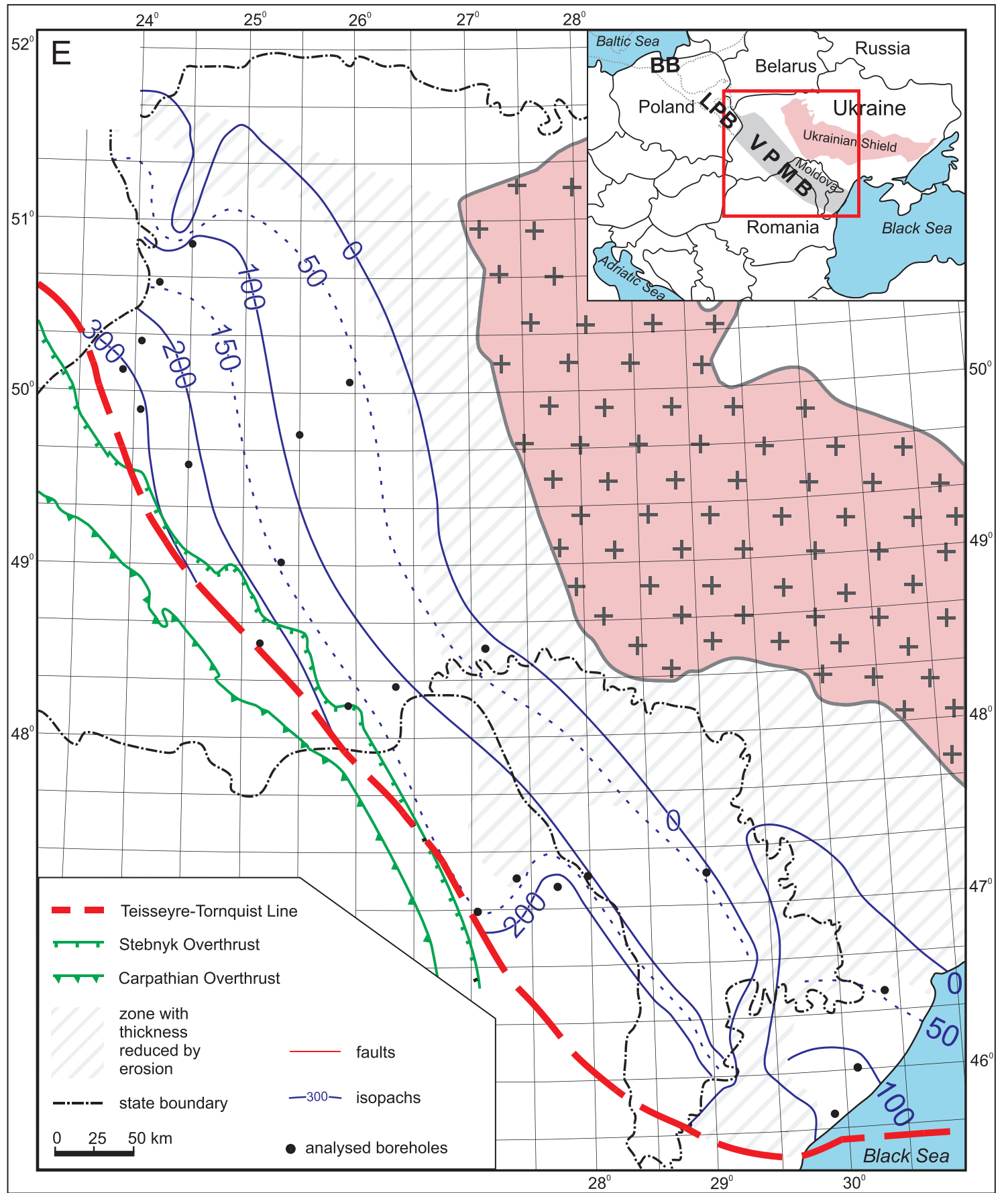

Fig. $6 \mathrm{E}$ - thickness maps for the following stratigraphic and lithostratigraphic units of the Volyn-Podillya-Moldavia Basin

Wenlock

sedimentation rate of the Middle Devonian succession is in the range of $30-55 \mathrm{~m} / \mathrm{My}$ and $110-120 \mathrm{~m} / \mathrm{My}$ for the Volyn-Podillya Plate and the Dobrogean zone, respectively (Fig. 5A, $B, E)$. The Upper Devonian in this region is also characterized by a westward lateral thickness increase, with a maximum thickness of $1300 \mathrm{~m}$ achieved in the region of the Velyki Mosty 30 borehole (Fig. 6K). Maximum sedimentation rates for the Upper Devonian in the Volyn-Podillya Plate are in range of 180-195 m/My for the Frasnian and 55-75 m/My for the Famennian (Fig. 5A, B).
During the latest Devonian to earliest Carboniferous, a significant tectonic uplift affected the whole basin analysed, except for its NW limits (boreholes: Volodymyr Volynsky 1, Litovyzh 1), resulting in locally intense erosion (Fig. 5). This is followed by a relatively short-term early Carboniferous phase of subsidence, which, however, does not comply with subsidence curve shapes indicative of any specific tectonic regime (Fig. 5A). In the western Volyn-Podillya sub-basin, sedimentation rate for that time span is in the range of $20-35 \mathrm{~m} / \mathrm{My}$ (Fig. 5A). The second phase of major uplift and erosion took place in the VPMB during the late Carboniferous to early Permian. 


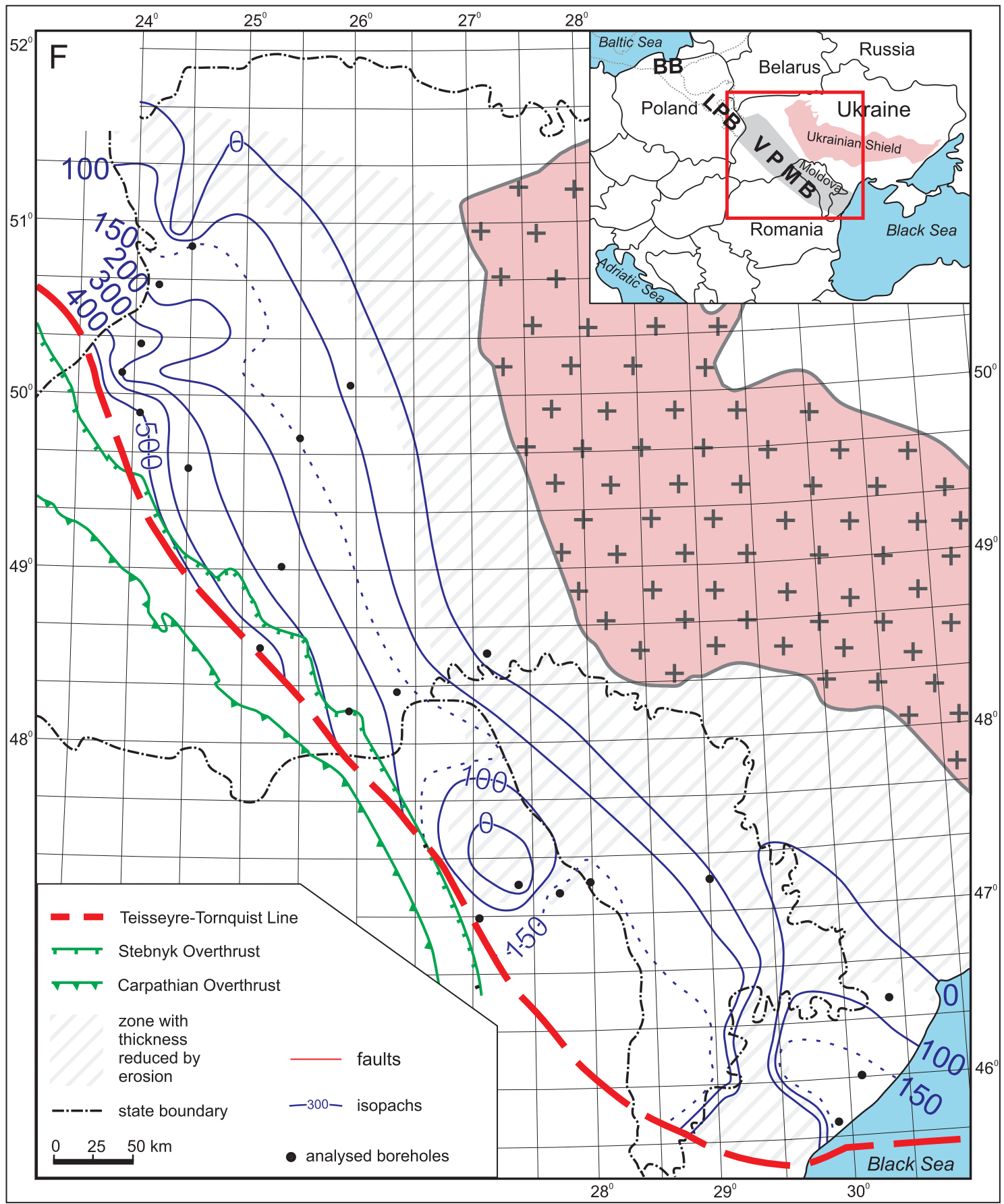

Fig. $6 \mathrm{~F}$ - thickness maps for the following stratigraphic and lithostratigraphic units of the Volyn-Podillya-Moldavia Basin

Ludlow

\section{DISCUSSION}

The pattern of the Ediacaran to Ordovician tectonic subsidence in the VPMB is characteristic of rift basins evolving into post-rift thermal sag basins (Fig. 5). The syn-rift extension phase took place during the Ediacaran, while post-rift thermal subsidence governed basin development from the latest Ediacaran to the Ordovician. The magnitude of syn-rift and post-rift tectonic subsidence increased towards the SW, and in the northern part of the study area also towards the north (Figs. 5 and $6 \mathrm{~A}-\mathrm{C}$ ). This indicates that the Ediacaran rift zone was located farther west of the current EEC edge, as well as in the Orsha-Volyn Aulacogen (see Fig. 1A for location).

The Ediacaran extensional tectonic subsidence event was initiated with the emplacement in the northern and western part of the VPMB of rift-related magmatic rocks, mainly basalts (Fig. 7A). Inference of the rift-related origin of the Ediacaran volcanic rocks in the study area is based only on petrological constraints, though farther to the $\mathrm{N}$ and $\mathrm{NW}$, in the Lublin Basin and 


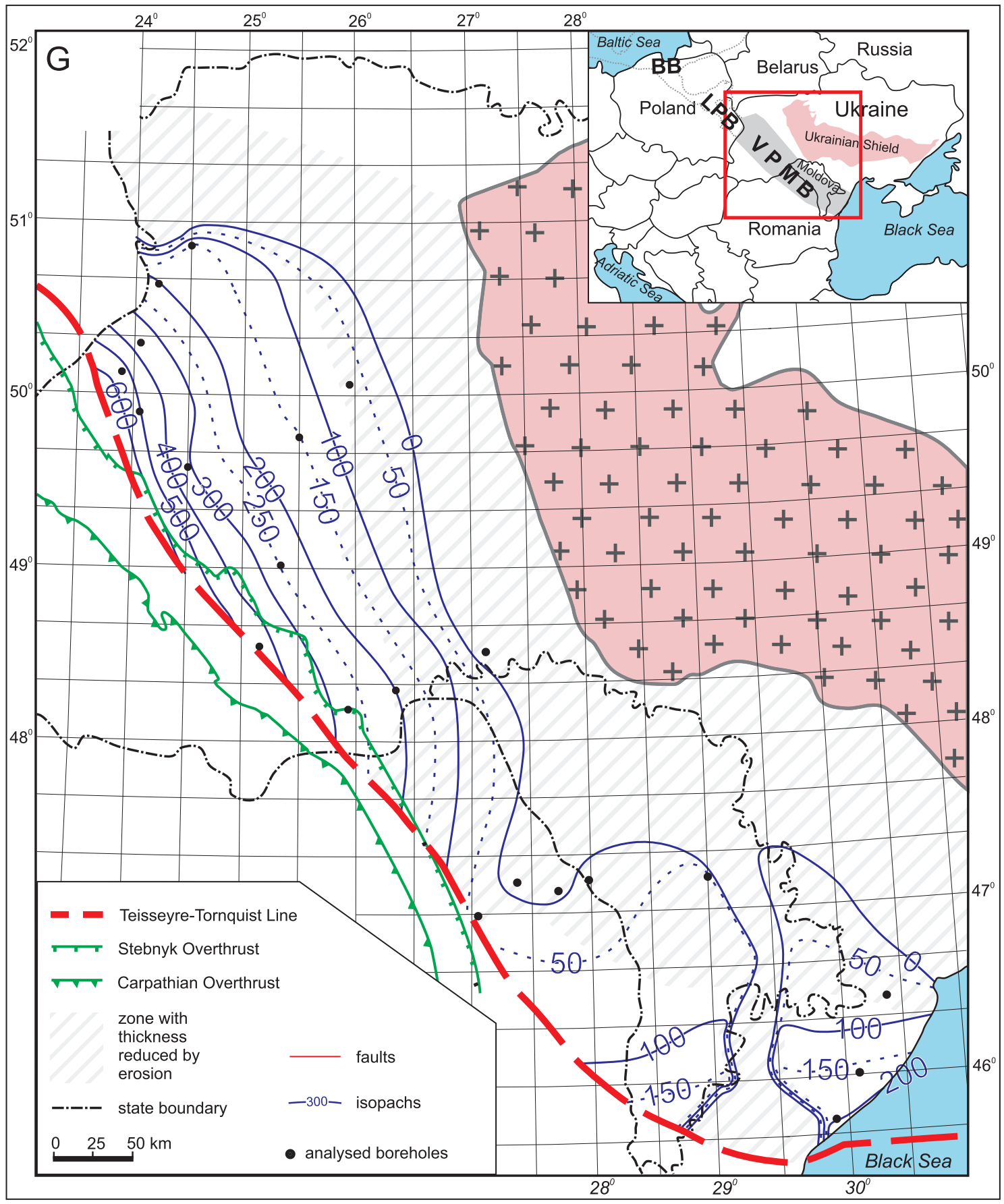

Fig. 6G - thickness maps for the following stratigraphic and lithostratigraphic units of the Volyn-Podillya-Moldavia Basin

Pridoli

Orsha-Volyn Aulacogen, such a tectonic environment of Ediacaran magmatic activity is supported by results of geochemical analyses (Białowolska et al., 2002; Bakun-Czubarow et al., 2002; Emetz et al., 2004; Krzemińska, 2005). A late Ediacaran age of the rift-related succession in the Lublin Basin and Orsha-Volyn Aulacogen is documented by radiometric geochronology of the volcanic and pyroclastic rocks (see "Methodology and Data" for more details; Savchenko et al., 1984; Sokolov and Fedonkin, 1990; Compston et al., 1995, Velikanov and Korenchuk, 1997; Shumlyanskyy and Andréasson, 2004; Elming et al., 2007; Shumlyanskyy et al., 2007).
This interpretation of the Ediacaran to Ordovician subsidence pattern in the VPMB is coherent with backstripping results obtained for the other part of the western EEC margin farther NW, i.e. for the Lublin-Podlasie Basin (Poprawa and Pacześna, 2002; Poprawa, 2006a), as well as the Baltic Basin (Poprawa et al., 1999; Poprawa, 2006a) and Western Scandinavia (Greiling et al., 1999; Eriksson, 2012). This model is also consistent with the facies development of the Ediacaran to Cambrian clastic fill of the Lublin-Podlasie Basin, which is adjacent to the area analysed (Poprawa and Pacześna, 2002; Pacześna and Poprawa, 2005; Pacześna, 2006, 2010, 2014). 


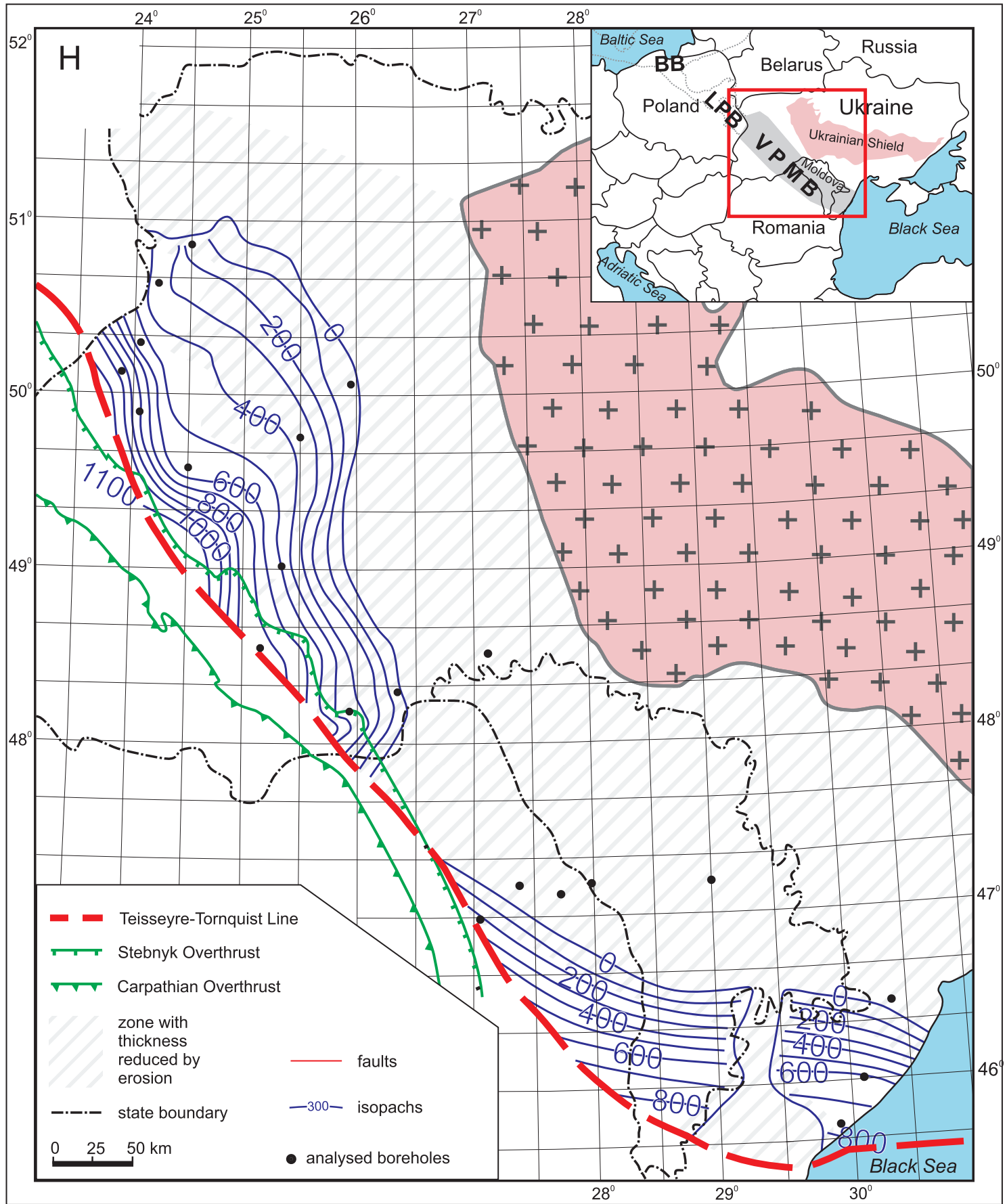

Fig. $6 \mathrm{H}$ - thickness maps for the following stratigraphic and lithostratigraphic units of the Volyn-Podillya-Moldavia Basin

Lochkovian (after Radkovets, 2016)

Additionally, the facies development of the late Ediacaran succession in the VPMB is coherent with the model of transition from syn-rift to post-rift deposition. The syn-rift volcanoclastic Volyn Series passes up-section into conglomerates, which are covered by coarse- and fine-grained sandstone and are replaced in turn by mudstones and claystones (Fig. 2). Therefore, the whole upper Ediacaran Mohyliv-Podilskyi and Kanyliv Series are characterized by a general fining-upward grain size trend and a decrease in sedimentation rate with time.
The Ediacaran rift-related extension is documented by new deep seismic data in the Lublin Basin directly to the NW of the area studied, where a large extensional half-graben has been identified. The graben developed in the Paleoproterozoic crystalline basement and was filled with a presumably upper Neoproterozoic syn-rift volcano-sedimentary succession (Krzywiec et al., 2018). A Neoproterozoic half-graben of similar scale was documented by deep seismic reflection data also farther to the NW at the western EEC margin in the SW part of the Baltic Sea (Lassen et al., 2001). 


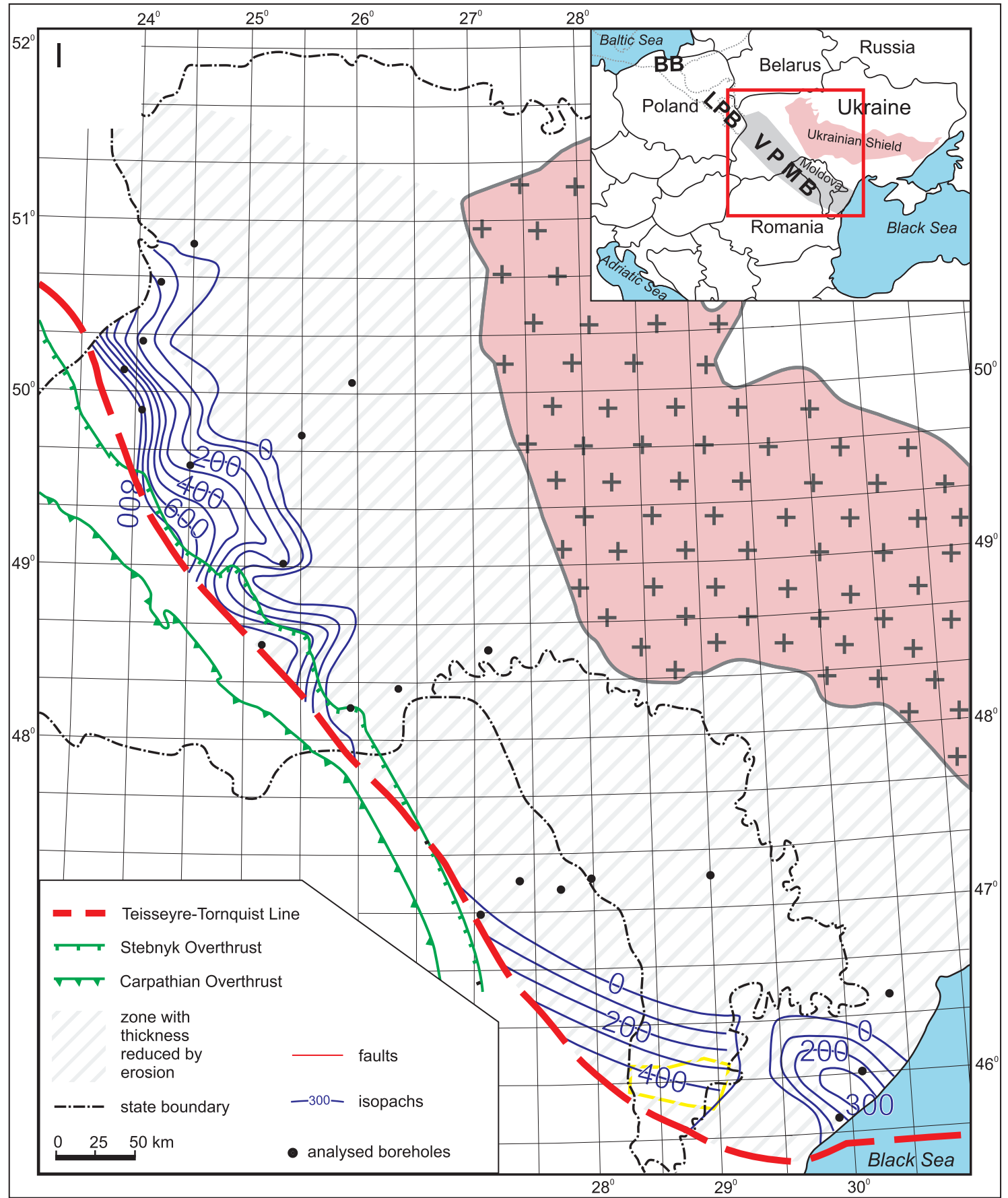

Fig. $6 \mathrm{I}$ - thickness maps for the following stratigraphic and lithostratigraphic units of the Volyn-Podillya-Moldavia Basin

Pragian and Emsian (after Radkovets, 2016)

Compilation of the above-mentioned subsidence analysis results and other data indicates that the Ediacaran rift developed along the whole SW margin of the EEC from Scandinavia to the Black Sea. This rifting was previously correlated with the break-up of the Precambrian supercontinent Rodinia/Pannotia and ultimately with the formation of the Tornquist Ocean (Poprawa et al., 1999; Poprawa and Pacześna, 2002). Such a concept is also coherent with palaeomagnetic data (e.g., Dalziel, 1992; Torsvik et al., 1996). Ediacaran rifting along the SW mar- gin of the EEC was coeval with rifting within the western part of the Orsha-Volyn Aulacogen (Poprawa and Pacześna, 2002).

Following the Ediacaran extension, magmatic activity and syn-rift subsidence, the study area became part of a late Ediacaran-early Paleozoic system of sedimentary basins that was developed along the whole SW margin of Baltica. From the latest Ediacaran throughout the Cambrian and Ordovician, a gradual decrease of tectonic subsidence is observed in the VPMB, resulting in a characteristic syn-rift to post-rift tectonic 


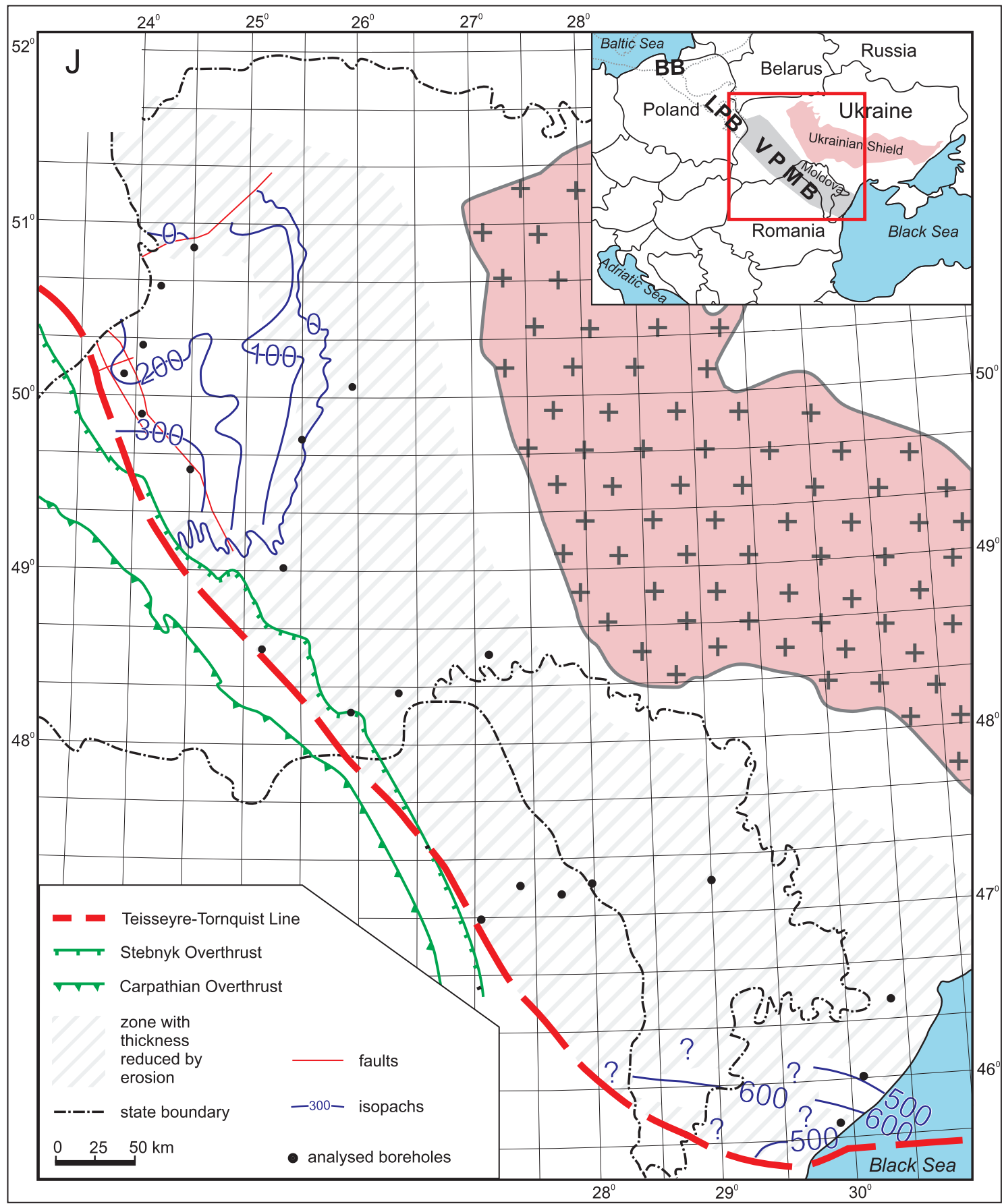

Fig. $6 \mathrm{~J}$ - thickness maps for the following stratigraphic and lithostratigraphic units of the Volyn-Podillya-Moldavia Basin

Middle Devonian (after Radkovets et al., 2017, supplemented)

subsidence pattern (Fig. 5). This indicates that during the Cambrian and Ordovician the major mechanism governing basin development was post-rift thermal sag. Such a concept is coherent with the results of subsidence analysis performed farther NW along the western EEC slope, i.e. in the Lublin-Podlasie Basin (Poprawa and Pacześna, 2002; Poprawa, 2006a) and the Baltic Basin (Poprawa et al., 1999; Poprawa, 2006a). The subsidence pattern described above supports a hypothesis that since the Ediacaran the SW margin of the newly formed Baltica from
Scandinavia to the Black Sea became a passive continental margin related to the formation of the Tornquist Ocean (Fig. 7A).

Subsidence during the thermal sag stage in the VPMB was interrupted by the latest Cambrian (to earliest Ordovician?) phase of uplift and erosion, incoherent with the model of the passive margin. The uplift extended farther NW along the EEC margin. In the nearby Lublin-Podlasie Basin, as well as in the southern and eastern Baltic Basin, the upper Cambrian is represented by a hiatus, though erosion of the middle Cambrian 


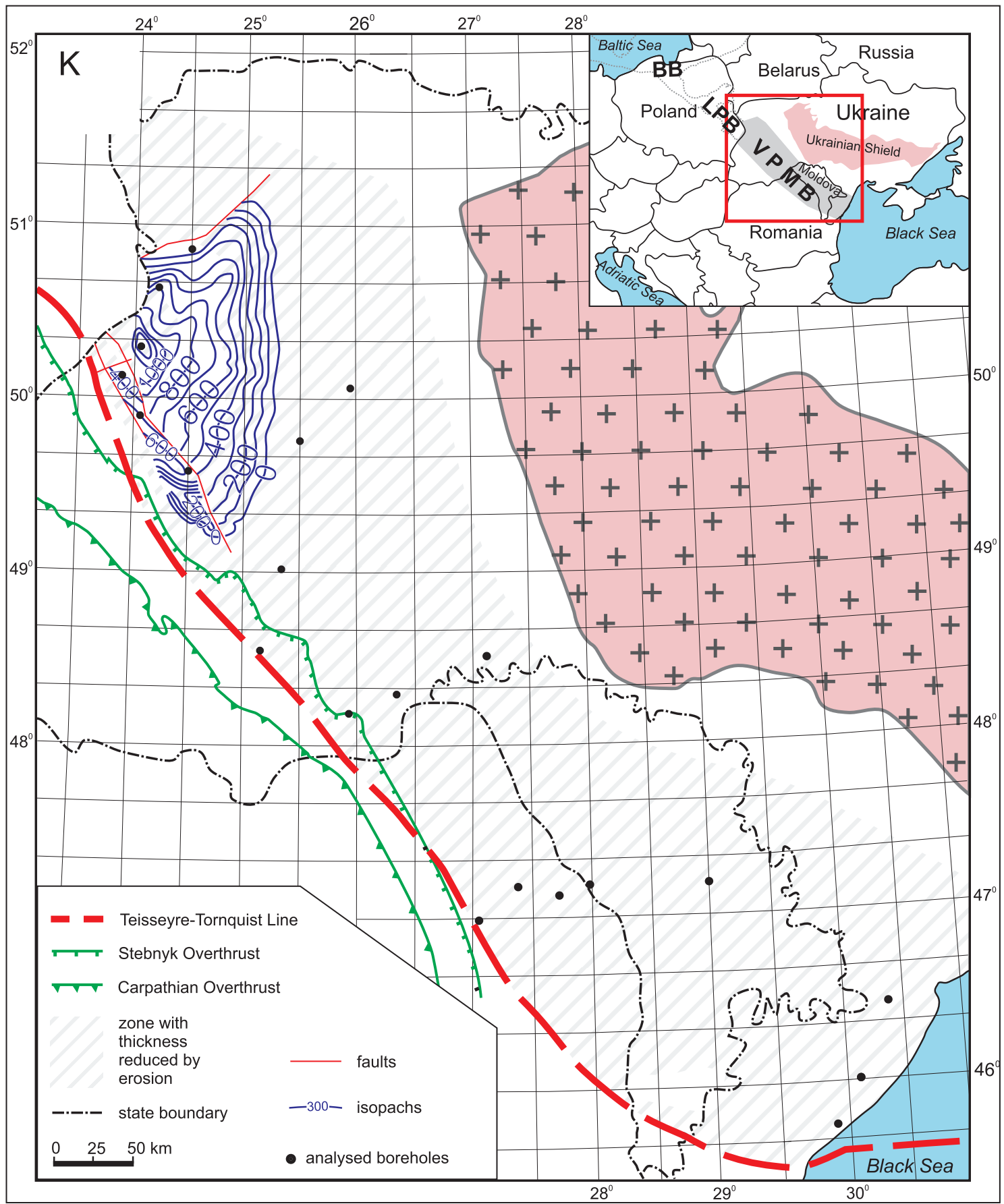

Fig. $6 \mathrm{~K}$ - thickness maps for the following stratigraphic and lithostratigraphic units of the Volyn-Podillya-Moldavia Basin

Upper Devonian (after Radkovets et al., 2017, modified);

due to the limited amount of data, map A should be regarded as tentative

deposits is limited. In the VPMB, uplift was more significant, and the whole middle and upper Cambrian succession was removed, except in the western Volyn-Podillya sub-basin and the southern Moldavia-Dobrogea sub-basin (see the extent of erosion in Fig. 6C). As the tectonic mechanism of uplift at the western margin of the EEC, compression related to the oblique docking of the Małopolska Block to the EEC has been proposed (Poprawa, 2006a). This, however, would be difficult to reconcile with the concept of a passive continental margin. Therefore, the late Cambrian uplift and erosion could alternatively be related to a far-field effect of contractional events or intra-plate stresses.

From the Wenlock, the pattern of subsidence in the VPMB changed significantly. A new phase of rapid and accelerating subsidence is observed for the Wenlock to Lochkovian time span, creating subsidence curves with convex shapes typical of foreland basin development (Fig. 5). The rate of WenlockLochkovian tectonic subsidence increases significantly in the direction of the SW margin of the EEC, i.e. towards the location 
A

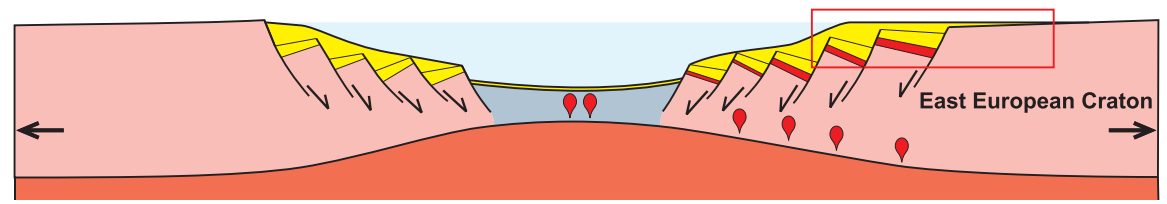

B

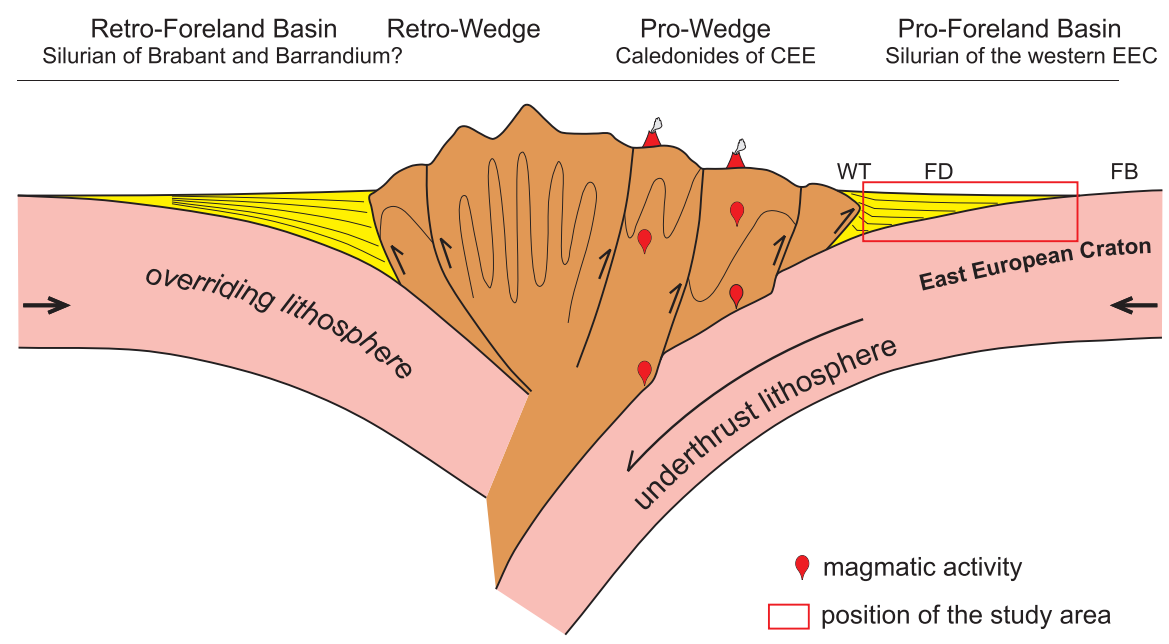

Fig. 7. Summary cartoon figure illustrating major tectonic mechanisms controlling development of the sedimentary basins at the western slope of the East European Craton

A - Ediacaran extension resulted in development of the rift basin and subsequent transition to the passive continental margin (after Poprawa, 2006a, modified); EEC - East European Craton; B - Silurian collision and development of foredeep basin (after Tari et al., 2016, supplemented); CEE - central and eastern Europe, WT - wedge top, FD - foredeep, FB - forebulge

of a collision-related tectonic load. Therefore, the Wenlock-Lochkovian VPMB is interpreted here as a Caledonian flexural foredeep (Fig. 7B). Such an interpretation is consistent with the subsidence analysis performed for the basins located farther NW, i.e. the adjacent Lublin-Podlasie Basin, as well as the Baltic Basin (Poprawa et al., 1999; Poprawa and Pacześna, 2002; Lazauskienè et al., 2002; Poprawa, 2006b; Tari et al., 2014, 2016; Mazur et al., 2018). In the Baltic Basin, the Silurian foredeep model is also supported by deep seismic data illustrating seismic horizons onlapping eastwards, i.e. outwards of the collision zone (Fig. 7B; Krzywiec et al., 2014; Mazur et al., 2016). The lesser thickness of the Caledonian foredeep sedimentary fill in the VPMB compared with the Lublin-Podlasie Basin and Baltic Basin might indicate a more distal (south-eastward) position of the VPMB relative to a Caledonian collision zone and the associated tectonic load.

An association of the Caradoc subsidence with the Caledonian foredeep in the study area remains uncertain due to an Ashgill and Llandovery hiatus. An assumption that the flexural foredeep phase of the basin development might have begun in the Caradoc time is supported by subsidence development in the adjacent Lublin-Podlasie Basin (Poprawa and Pacześna, 2002; Poprawa, 2006b), where the section at the transition from the Ordovician to Silurian is more complete. In such a model, a lack of Ashgill deposits might be explained by a low eustatic sea level, as documented by Ross and Ross (1990). However, the Llandovery eustatic sea level rise suggests a different explanation for the lack of strata of this age in the basin, which might be a forebulge effect in front of the Caledonian collision zone, which was progressing obliquely from the NW to the SE along the western margin of the EEC. Nonetheless, according to Torsvik and Rehnström (2003), collision between Avalonia and Baltica commenced in the Ashgill, and if their data are corrected a tectonic load could not have existed in the Caradoc (cf. Mazur et al., 2018). With the current data, the timing of the beginning of the Caledonian foredeep flexure development in the VPMB cannot be conclusively constrained.

The concept of a flexural foredeep is coherent with a depositional model for Silurian sedimentation. During the Silurian two deposition zones existed in the basin, contrasting with each other in facies development: the NE zone of the basin was a site of shallow marine carbonate deposition (lagoon and reef), while the SW zone of the basin, i.e. zone proximal to the Teisseyre-Tornquist Zone, there accumulated open shelf mudstone, marl and claystone (Skompski et al., 2008; Łuczyński et al., 2009; Radkovets, 2015). Since the open shelf was isolated from the EEC interior by the reef and lagoon zone, most of the detritus delivered to the basin during the Silurian must have been supplied from the west, i.e. from the convergent plate margin. High sedimentation rates of the Wenlock to Pridoli mudstone (Fig. 5A-E) are therefore interpreted here as reflecting tectonic activity within the provenance area during this relatively long interval. Uplift within the Caledonian fold-and-thrust belt, related to progressing convergence, might have been a sufficient mechanism allowing for rapid detritus supply to the basin in the Silurian. During the Lochkovian this zonation did not exist in the basin any more (Radkovets, 2016), therefore the basin could have been supplied with detritus both from the collision zone located to the west and the craton interior located in the east.

A model of Silurian to Lochkovian convergence along the western margin of the EEC (Baltica) is supported by the common presence of numerous bentonite layers of that age in the VPMB, as documented e.g. by Huff et al. (2000) and Radkovets (2016). This is part of a large volcanic ash province, which through Late Ordovician to Early Devonian time was deposited extensively along the whole western slope of the EEC. Lateral changes in the thickness and number of bentonite layers clearly indicate that the 
source was located to the west of Baltica, while the geochemical characteristics of the bentonites suggests subduction-related island arc volcanism as a source (Huff et al., 1992, 2000; Bergström et al., 1995). Caledonian oblique convergence between Baltica and Avalonia is supported also by palaeomagnetic data (Torsvik et al., 1996; Torsvik and Rehnström, 2003).

The foredeep phase of the basin development terminated prior to the Pragian which was characterized by decreased tectonic subsidence and sedimentation rates (Fig. 5) as well as by major facies changes into terrigenous Old Red clastics (Radkovets, 2016). The Old Red facies sedimentation continued until the Emsian. The Pragian-Emsian subsidence of the basin is interpreted here as a lithospheric isostatic imbalance inherited from the Caledonian collision. At this stage, the VPMB became part of an extensive system of European post-collisional Old Red basins (Radkovets, 2016), which developed as a result of extensional collapse of overthickened crust and/or sinistral transtension along the lapetus suture (Ziegler, 1988; Friend et al., 2000; Dewey and Strachan, 2003).

At the transition from the Early to Middle Devonian, tectonic uplift and erosion took place locally resulting in truncations, which were identified using a geological cross-section attached to the Geological Map of Ukraine by Gerasimov et al. (2003). This might indicate a temporary change of tectonic regime into a compressional setting. Local uplift and erosion of that age was also observed farther NW in the Lublin-Podlasie Basin.

Tectonic subsidence analysis of the Middle and Upper Devonian to Carboniferous phase of the basin evolution was limited to the western part of the Volyn-Podillya Plate and southern Dobrogea Trough, the only parts of the basin where deposits of this age are preserved. Phases of short-term rapid subsidence in isolated small depocentres, observed primarily in the Frasnian (Fig. 5), are coherent with a transtensional tectonic model. A similar pattern of Late Devonian tectonic subsidence was observed for the nearby Lublin Basin, with comparable interpretation (Narkiewicz et al., 1998). During the latest Devonian to early Carboniferous, tectonic uplift led to erosion of a significant part of the Devonian and the lower Paleozoic sections. This uplift is also observed at a larger scale in the Lublin Basin.

\section{CONCLUSIONS}

1. The development of the VPMB commenced with an event of relatively rapid tectonic subsidence in the late Ediacaran, which was followed by systematically decreasing subsidence during the Cambrian and Ordovician. Such a pattern of subsidence is characteristic of evolution from a syn-rift basin to post-rift thermal sag. The rift origin of the basin is supported by emplacement of rift-related Ediacaran volcanic rocks along both the western edge of the East European Craton and within the western Orsha-Volyn Aulacogen.

2. The Ediacaran rift developed along the whole SW margin of the East European Craton from Scandinavia to the Black Sea. Development of this large extensional basin was related to the latest stages of break-up of the Precambrian supercontinent Rodinia/Pannotia and ultimately the formation of the Tornquist Ocean. During the post-rift thermal sag stage, the SW margin of the newly formed Baltica, including the area studied, became a passive continental margin.

3. From the Late Ordovician, a gradual change of tectonic regime into a collisional setting is observed across the SW margin of Baltica. In the study area, this is indicated by a systematic increase in subsidence rate from Wenlock to Lochkovian time, creating subsidence curves with convex shapes typical of foreland basin development. The Silurian to Early Devonian VPMB is therefore interpreted here as a flexural foredeep, related to development of the Caledonian collision zone farther west. Convergence-related uplift within the Caledonian fold-andthrust belt might have been a sufficient mechanism allowing for supply of fine-grained detritus to the basin in the Silurian. The prominent diachroneity of the initiation of foredeep basin development at the scale of the whole SW margin of Baltica is coherent with a model of oblique collision of Avalonia and Baltica.

4. During the Pragian-Emsian, the basin was part of a system of post-collisional Old Red basins, with subsidence presumably governed by lithospheric post-collisional isostatic imbalance. At the transition from the Early to Middle Devonian, tectonic uplift and erosion took place locally resulting in truncations, which are also observed farther NW in the Lublin Basin. This might indicate a temporary change of tectonic regime into compression.

5. The Middle to Late Devonian short-term phases of rapid subsidence in small depocentres, observed on the western part of the Volyn-Podillya Plate and in the southern Dobrogea Trough, might be regarded as an indication of a transtensional tectonic regime. During the latest Devonian to early Carboniferous, tectonic uplift led to erosion of a significant part of the Devonian and lower Paleozoic sections.

Acknowledgements. We kindly acknowledge S. Porębski and M. Paszkowski for inspiring discussions. The contribution of the senior author was financed by the National Science Centre (NCN), grant No. 2012/05/B/ST10/00521. Constructive comments and suggestions from the reviewers, S. Mazur and $\mathrm{G}$. Tari, helped greatly to improve the manuscript.

\section{REFERENCES}

Allen, P.A., Allen, J.R., 1990. Basin Analysis - Principles and Applications. Blackwell Science Publications, Oxford.

Angevine, Ch.L., Heller, P.L., Paola, Ch., 1990. Quantitative sedimentary basin modelling. AAPG Continuing Education Course Note Series, 32.

Bakun-Czubarow, N., Białowolska, A., Fedoryshyn, Y., 2002. Neoproterozoic flood basalts of Zabolottya and Babino Beds of the volcanogenic Volhynian Series and Polesie Series dolerites in the western margin of the East European Craton. Acta Geologica Polonica, 52: 481-496.
Barton, N., Wood, R., 1984. Tectonic evolution of the North Sea basin: crustal stretching and subsidence. Geophysical Journal of the Royal Astronomical Society, 79: 987-1022.

Bergström, S.M., Huff, W.D., Kolata, D., Bauert, K., 1995. Nomenclature, stratigraphy, chemical fingerprinting, and areal distribution of some Middle Ordovician K-bentonites in Baltoscandia. Geologiska Föreningen i Stockholm Förhandlingar, 117: 1-13

Białowolska, A., Bakun-Czubarow, N., Fedoryshyn, Y., 2002. Neoproterozoic flood basalts of the upper beds of the Volhynian 
Series (East European Craton). Geological Quarterly, 46 (1): 37-58.

Bond, G.C., Nickeson, P.A., Kominz, M.A., 1984. Breakup of a supercontinent between $625 \mathrm{Ma}$ and $555 \mathrm{Ma}$ : new evidence and implications for continental histories. Earth and Planetary Science Letters, 70: 325-345.

Busby, C.J., Ingersoll, R.V., 1995. Tectonics of Sedimentary Basins. Blackwell Science Publications.

Chebanenko, I.I., Vishsnyakov, I.B., Vlasov, B.I., 1990. Geotektonika Volyno-Podolii (in Russian). Naukova Dumka, Kiev.

Cohen, K.M., Finney, S.C., Gibbard, P.L., Fan, J.-X., 2013. The ICS International Chronostratigraphic Chart. Episodes, 36: 199-204.

Compston, W., Sambridge, M.S., Reinfrank, R.F., Moczydlowska, M., Vidal, G., Claesson, S., 1995. Numerical ages of volcanic rocks and the earliest faunal zone within the Late Precambrian of east Poland. Journal of the Geological Society, 152: 599-611.

Dalziel, I.W.D., 1992. On the organization of American plates in the Neoproterozoic and the breakout of Laurentia. GSA Today, 2: 237-241.

Dewey, J.F., Strachan, R.A., 2003. Changing Silurian-Devonian relative plate motion in the Caledonides: sinistral transpression to sinistral transtension. Journal of the Geological Society, 160: 219-229.

Emetz, A., Piestrzyński, A., Zagnitko, V., 2004. Geological framework of the Volhyn copper fields with a review of the Volhyn flood basalt province (western margin of the East-European Craton). Annales Societatis Geologorum Poloniae, 74: 257-265.

Elming, S.A., Kravchenko, S.N., Layer, P., Rusakov, O.M., Glevasskaya, A.M., Mikhailova, N.P., Bachtads, E.V., 2007. Palaeomagnetism and ${ }^{40} \mathrm{Ar} /{ }^{39} \mathrm{Ar}$ age determinations of the Ediacaran traps from the southwestern margin of the East European Craton, Ukraine: relevance to the Rodinia break-up. Journal of the Geological Society, 164: 969-982.

Eriksson, M., 2012. Stratigraphy, facies and depositional history of the Colonus Shale Trough, Skåne, southern Sweden. Department of Geology, Lund University.

Falvey, D.A., Middleton, M.F., 1981. Passive continental margins: evidence for a prebreakup deep crustal metamorphic subsidence mechanism. Oceanologica Acta, SP: 103-114.

Friend, P.F., Williams, B.P.J., Ford, M., Williams, E.A., 2000. Kinematics and dynamics of Old Red Sandstone basins. Geological Society Special Publications, 180: 29-60.

Gareckij, R.G., Zinovienko, G.V., Visnjakov, I.B., Glusko, V.V., Pomjanovskaja, G.M., Lvov, G.M., 1987. Die perikratone Baltik-Dnestr-Senkungszone. Zeitschrift für angewandte Geologie, 33: 207-213.

Gerasimov, L.S., Thaliy, S.V., Gerasimova, I.I., Velikanov, V.Ya., 2003. Geological Map of Ukraine 1:200 000 - M-34-XVIII (Rava Ruska) and M-35-XIII (Thervonograd) (in Ukrainian). Ukrainian Ministry of Ecology and Natural Resources, National Geological Survey, Ukraine.

Gerasimov, M.Y., Bondarchuk, G.K., Skoryk, A.M., Koltsov, S.V., Fedorchuk, V.F., Dyakovich, P.I., 2006. Geodinamika, seysmichnost i neftegazonosnost Chernomorsko-Kaspiyskogo regiona (in Russian). In: Tektonichna karta pivdnya Ukrainy z pozytsiy aktualistychnoy geodynamiky. Sbornik dokladov VI Mezhdunarodnoy konferentsii “Krym-2005”, Simferopol: 11-40.

Gnidets, V.P., Grigorchuk, K.G., Polukhtovych, B.M., Fedyshyn, V.O., 2002. Lithogenesis of Devonian deposits of Dobrogea Foredeep (palaeooceanography, sedimentary cyclicity, reservoir rocks' formation) (in Ukrainian with English summary). UkrDGRI, Lviv.

Greiling, R.O., Jensen, S., Smith, A.G., 1999. Vendian-Cambrian subsidence of the passive margin of western Baltica - application of new stratigraphic data from the Scandinavian Caledonian margin. Norsk Geologisk Tidsskrift, 77: 133-144.

Huff, W.D., Bergström, S.M., Kolata, D., 1992. Giantic Ordovician volcanic ash fall in North America and Europe: biological, tectonomagmatic, and event-stratigraphic significance. Geology, 20: 875-878.
Huff, W.D., Bergström, S.M., Kolata, D.R., 2000. Silurian K-bentonites of the Dnestr Basin, Podolia, Ukraine. Journal of the Geological Society, 157: 493-504.

King, L.M., 1994. Subsidence analysis of Eastern Avalonia sequences: implications for lapetus closure. Journal of the Geological Society, 151: 647-657.

Kominz, M., 1995. Thermally subsiding basin and the insulating effect of sediment with application to the Cambro-Ordovician Great Basin sequence, western USA. Basin Research, 7: 221-233.

Kosakowski, P., Radkovets, N., Rauball, J., Zakrzewski, A., 2017. Occurrence and burial and thermal history of the Ediacaran strata (W-SW Ukraine and Moldova). 79th EAGE Conference and Exhibition 2017, Paris, France, 12-15 June 2017. DOI: 10.3997/2214-4609.201700619

Kruglov, C.C., Tsypko, A.K., 1988. Tektonika Ukrainy (in Russian). Nedra, Moscow.

Krzemińska, E., 2005. The outline of geochemical features of the Late Neoproterozoic volcanic activity in the Lublin-Podlasie basin, eastern Poland. Mineralogical Society of Poland, Special Papers, 26: 47-51.

Krzywiec, P., Malinowski, M., Lis, P., Buffenmyer, V., Lewandowski, M., 2014. Lower Paleozoic basins developed above the East European Craton in Poland: new insight from regional high-effort seismic reflection data. SPE/EAGE European Unconventional Resources Conference and Exhibition, Vienna (extended abstract), Book of Abstracts, SPE-167739-MS.

Krzywiec, P., Poprawa, P., Mikołajczak, M., Mazur, S., Malinowski, M., 2018. Deeply concealed half-graben at the SW margin of the East European Craton (SE Poland) - evidence for Neoproterozoic rifting prior to the break-up of Rodinia. Journal of Palaeogeography, 7: 88-97.

Lassen, A., Thybo, H., Berthelsen, A., 2001. Reflection seismic evidence for Caledonian deformed sediments above Sveconorwegian basement in the southwestern Baltic Sea. Tectonics, 20: 268-276.

Lazauskienè, J., Stephenson, R., Šliaupa, S., Van Wees, J.-D., 2002. 3-D flexural modelling of the Silurian Baltic Basin. Tectonophysics, 346: 115-135.

Levy, M., Christie-Blick, N., 1991. Tectonic subsidence of the early Palaeozoic passive continental margin in eastern California and southern Nevada. GSA Bulletin, 103: 1590-1606.

Łuczyński, P., Skompski, S., Kozłowski, W., 2009. Sedimentary history of Upper Silurian biostromes of Podolia (Ukraine) based on stromatoporoid morphometry. Palaeogeography, Palaeoclimatology, Palaeoecology, 271: 225-239.

Mazur, S., Mikolajczak, M., Krzywiec, P., Malinowski, M., Lewandowski, M., Buffenmyer, V., 2016. Pomeranian Caledonides, NW Poland - a collisional suture or thin-skinned fold-and-thrust belt? Tectonophysics, 692: 29-43.

Mazur, S., Porębski, S.J., Kedzior, A., Paszkowski, M., Podhalańska, T., Poprawa, P., 2018. Refined timing and kinematics for Baltica-Avalonia convergence based on the sedimentary record of a foreland basin. Terra Nova, 30: 8-16.

McKenzie, D., 1978. Some remarks on the development of sedimentary basins. Earth and Planetary Science Letters, 40: 25-32.

Narkiewicz, M., Poprawa, P., Lipiec, M., Matyja, H., Miłaczewski, L., 1998. Paleogeographic and tectonic setting and the Devonian-Carboniferous subsidence development of the Pomerania and Radom-Lublin regions (in Polish with English summary). Prace Państwowego Instytutu Geologicznego, 165: 31-49.

Pacześna, J., 2006. Evolution of late Neoproterozoic rift depocentres and facies in the Lublin-Podlasie sedimentary basin (in Polish with English summary). Prace Państwowego Instytutu Geologicznego, 186: 9-38

Pacześna, J., 2010. The evolution of late Ediacaran riverine-estuarine system in the Lublin-Podlasie slope of the East European Craton, southeastern Poland. Polish Geological Institute Special Papers, 27.

Pacześna, J., 2014. Lithostratigraphy of the Ediacaran deposits in the Lublin-Podlasie sedimentary basin (eastern and south-east- 
ern Poland). Biuletyn Państwowego Instytutu Geologicznego, 460: 1-24.

Pacześna, J., Poprawa, P., 2005. Eustatic versus tectonic control on the development of Neoproterozoic and Cambrian stratigraphic sequences of the Lublin-Podlasie Basin (SW margin of Baltica). Geosciences Journal, 9: 117-127.

Pătruț, I, Dăneț, T., 1987. Le Precambrien (Vendien) et le Cambrien dans la Plateforme Moldave (in Romanian with French abstract). Analele Ştiințifice ale Universității "Al.I.Cuza" Iaşi, s. II-b, 33: 26-30.

Poprawa, P., 2006a. Neoproterozoic break-up of the supercontinent Rodiania/Pannotia recorded by development of sedimentary basins at the western slope of Baltica (in Polish with English summary). Prace Państwowego Instytutu Geologicznego, 186: 165-188.

Poprawa, P., 2006b. Development of the Caledonian collision zone along the western margin of Baltica and its relation to the foreland basin (in Polish with English summary). Prace Państwowego Instytutu Geologicznego, 186: 189-214.

Poprawa, P., Pacześna, J., 2002. Late Neoproterozoic to Early Paleozoic development of a rift at the Lublin-Podlasie slope of the East European Craton - analysis of subsidence and facies record (in Polish with English summary). Przegląd Geologiczny, 50: 49-61.

Poprawa, P., Šliaupa, S., Stephenson, R.A., Lazauskiene, J., 1999. Late Vendian-Early Palaeozoic tectonic evolution of the Baltic basin: regional implications from subsidence analysis. Tectonophysics, 314: 219-239.

Radkovets, N., 2015. The Silurian of southwestern margin of the East European Platform (Ukraine, Moldova and Romania): lithofacies and palaeoenvironments. Geological Quarterly, 59 (1): 105-118.

Radkovets, N., 2016. Lower Devonian lithofacies and palaeoenvironments in the south western margin of the East European Platform (Ukraine, Moldova and Romania). Estonian Journal of Earth Sciences, 65: 207-220.

Radkovets, N.Y., Kotarba, M., Wójcik, K., 2017. Source rock geochemistry, petrography of reservoir horizons and origin of natural gas in the Devonian of the Lublin and Lviv basins (SE Poland and western Ukraine). Geological Quarterly, 61 (3): 569-589.

Radkovets, N., Kosakowski, P., Rauball, J., Zakrzewski, A., 2018. Burial and thermal history modelling of the Ediacaran succession in Western and SW Ukraine and Moldova. Journal of Petroleum Geology, 41: 85-106.

Ross, C.A., Ross, J.R.P., 1990. The Paleozoic sea-level curve. In: A Geological Time Scale (eds. W.B. Harland, A.V. Cox, A.V. Llewellyn, C.A.G. Pickton, A.G. Smith and R. Walters). Cambridge University Press, Cambridge.

Savchenko, N.A., Bernadskaya, L.G., Dolgova, V.I., Buturlinov, N.V., Bugaenko, V.N., Semka, V.A., Bondarenko, V.G., Plakhotny, L.G., 1984. Palaeovolcanism of the Ukraine (in Russian). Naukova Dumka, Kiev.

Sclater, J.G., Christie, P.A.F., 1980. Continental stretching: an explenation of the post-Mid-Cretaceous subsidence of the Central North Sea Basin. Journal of Geophysical Research, 85: 3711-3739

Shulga, V.F., Zdanovski, A., Zaytseva, L.B., Ivanova, A.V., Ivanina, A.B., Korol, N.D., Kotasova, A., Kotas, A., Kostik, I.E., Lelik, B.I., Miger, T., Manichev, V.I., Matrofaylo, M.N., Ptak, B., Savchuk, V.S., Sedayeva, G.M., Stepanenko, Y.G., 2007. Correlation of the Carboniferous coal-bearing formation of the Lviv-Volyn and Lublin basins (in Russian with English summary). National Academy of Sciences of Ukraine, Institute of Geological Sciences and Polish State Geological Institute, Upper Silesian Branch, Kiev.

Shumlyanskyy, L., Andréasson, P.G., 2004. New geochemical and geochronological data from the Volyn Flood Basalt in
Ukraine and correlation with large igneous events in Baltoscandia. 26th Nordic Geological Winter Meeting, GFF, 126: 85-86.

Shumlyanskyy, L., Andréasson, P.G., Buchan, K.L., Ernst, R.E., 2007. The Volynian Flood Basalt Province and coeval (Ediacaran) magmatism in Baltoscandia and Laurentia. Mineralogical Journal, 29: 47-53.

Shumlyanskyy, L., Nosova, A., Billström, K., Söderlund, U., Andréasson, P.G., Kuzmenkova, O., 2016. The U-Pb zircon and baddeleyite ages of the Neoproterozoic Volyn Large Igneous Province: implication for the age of the magmatism and the nature of a crustal contaminant. GFF, 138: 17-30.

Skompski, S., Łuczyński, P., Drygant, D., Kozłowski, W., 2008. High-energy sedimentary events in lagoonal successions of Upper Silurian of Podolia, Ukraine. Facies, 54: 277-296.

Steckler, M.S., Watts, A.B., 1978. Subsidence of the Atlantic-type continental margin off New York. Earth and Planetary Science Letters, 41: 1-13.

Sokolov, B.S., Fedonkin, M.A., 1990. The Vendian System. Regional Geology, 2, Springer, Berlin.

Środoń, J., Paszkowski, M., Drygant, D., Anczkiewicz, A., Banaś, M., 2013. Thermal history of Lower Paleozoic rocks on the Peri-Tornquist Margin of the East European Craton (Podolia, Ukraine) inferred from combined XRD, K-Ar, and AFT data. Clays and Clay Minerals, 61: 107-132.

Tari, G., Poprawa, P., Krzywiec, P., Popadyuk, I., Krezsek, C., 2014. Interpretation of the Silurian Basin of Central and Eastern Europe as a pro-foreland flexural basin: implications for Shale Gas Exploration. Society of Petroleum Engineers, 14UNCV167744-MS

Tari, G., Poprawa, P., Krzywiec, P., Popescu, B., Micu, M., Krezsek, C., Rainer, T., 2016. Pro-foreland flexural basin interpretation of the Silurian Basin of Central and Eastern Europe: a reviews. AAPG Regional Conference, Bucharest, Abstract Book: 153-154, http://europeevents.aapg.org/Bucharest2016

Torsvik, T.H., Rehnström, E.F., 2003. The Tornquist Sea and Baltica-Avalonia docking. Tectonophysics, 362: 67-82.

Torsvik, T.H., Smethurst, M.A., Meert, J.G., Van Der Voo, R., Mckerrow, W.S., Brasier, M.D., Sturt, B.A., Walderhaug, H.J., 1996. Continental break-up and collision in the Neoproterozoic and Palaeozoic - a tale of Baltica and Laurentia. Earth-Science Review, 40: 229-258.

Vashchenko, V.O., Turchynova, S.M., Turchynov, I.I., Poliha, G.G., 2007. Derzhavna geologichna karta Ukrainy mashtabu 1:200 000 (in Ukrainian). Karpatska seria. Arkush M-35-XXV (Ivano-Frankivsk). UkrDGRI, Kyiv.

Velikanov, V.A., Korenchuk, L.V., 1997. Phases of magmatism and their relation to the sediment deposition in the Late Precambrian (Riphean-Vendian) of the Volhyn-Podolia. Geologichny Journal, (1-2): 124-131.

Velikanov, V.Y., Aseeva, E.A., Fedonkin, M.A., 1983. Vend Ukrainy (in Russian). Naukova Dumka, Kiev.

Vishnyakov, I.B., Glushko, V.V., Pomyanovskaya, G.M., 1981. Yugozapadnyi kray Vostochno-Yevropeyskoy platformy na Ukraine i v Moldavii (in Russian). In: Geologiya zapada Vostochno-Yevropeyskoy platformy (ed. R.G. Garetskiy): 22-35. Nauka i Tekhnika, Minsk.

Waldron, J.W.F., Murphy, J.B., Melchin, M.J., Davis, G., 1996. Silurian tectonics of Western Avalonia: strain-corrected subsidence history of the Arisaig Group, Nova Scotia. The Journal of Geology, 104: 677-694.

Ziegler, P.A., 1988. Laurussia - the Old Red continent. In: Devonian of the World: Proceedings of the 2nd International Symposium on the Devonian System (eds. N.J. McMillan, A.F. Embry and D.J. Glass). Memoir - Canadian Society of Petroleum Geologists, 14, Vol. (I): 15-48. 